\title{
RAZGLEDI
}

\section{PRIMERJAVA KULTURNE POKRAJINE HRAŠKIH LISTNEKOV IN TAMKAJŠNJEGA KMETOVANJA V PRVI POLOVICI 19. STOLETJA IN DANES}

AVTORJI

dr. Matjaž Geršič

Znanstvenoraziskovalni center Slovenske akademije znanosti in umetnosti, Geografski inštitut Antona Melika, Gosposka ulica 13, SI - 1000 Ljubljana, Slovenija

matjaz.gersic@zrc-sazu.si

\section{dr. Matej Gabrovec}

Znanstvenoraziskovalni center Slovenske akademije znanosti in umetnosti, Geografski inštitut Antona Melika, Gosposka ulica 13, SI - 1000 Ljubljana, Slovenija

matej@zrc-sazu.si

\section{dr. Žiga Zwitter}

Univerza $v$ Ljubljani, Filozofska fakulteta, Oddelek za zgodovino

Aškerčeva cesta 2, SI - 1000 Ljubljana

ziga.zwitter@ff.uni-lj.si

DOI: $10.3986 / G V 90104$

UDK: 911.53:63(497.4)"18"

COBISS: 1.01

\section{IZVLEČEK}

Primerjava kulturne pokrajine Hraških listnekov in tamkajšnjega kmetovanja v prvi polovici 19. stoletja in danes

Analiziramo območje Hraških listnekov v dnu Ljubljanske kotline, kjer je kulturna pokrajina ohranila v primerjavi $z$ okolico številne elemente, $k i$ so omogočali uspešno kmetovanje v preteklosti (mejice, razgiban relief), danes pa njihovo ohranjanje predstavlja poseben izziv. $Z$ njim se velja soočiti zaradi posebnega ekosistemskega pomena. Primerjava kategorij rabe tal in načinov kmetovanja v zgodnjem 19. in zgodnjem 21. stoletju dokazuje z ekosistemskega vidika pomembne kontinuitete in diskontinuitete. Za ustrezno ohranitev tamkajšnje kulturne pokrajine bo potrebeno mnogo bolj poglobljeno sodelovanje med kmeti in okoljevarstveniki od dosedanjega.

KLJUČNE BESEDE

geografija, okoljska zgodovina, kulturna pokrajina, podeželje, raba zemljišč, Gorenjska 


\begin{abstract}
Comparing the cultural landscape of Hraški Listneki and farming there in the first half of the nineteenth century and today

This article analyses the Hraše Leaf Litter Forests (Hraški Listneki) at the bottom of the Ljubljana Basin, where, unlike the surrounding area, the cultural landscape has preserved many elements that facilitated farming in the past (hedges between fields and rough terrain), but today their conservation represents a special challenge. This challenge is worth addressing because the area's ecosystem has special significance. A comparison of land-use categories and forms of farming in the early nineteenth and twenty-first centuries shows important continuities and discontinuities from an ecosystem perspective. Appropriate conservation of this cultural landscape calls for significantly stronger cooperation between farmers and nature conservationists than has taken place to date.
\end{abstract}

\title{
KEY WORDS
}

geography, environmental history, cultural landscape, countryside, land use, Upper Carniola

Uredništvo je prispevek prejelo 31. julija 2018. 


\section{Uvod}

Ohranjanje in varovanje kulturne pokrajine je pomemben razvojni izziv slovenskega podeželja. O tem posredno ali neposredno pišejo številni avtorji (na primer Urbanc 2002; Klemenčič 2006; Ažman Momirski in Kladnik 2009; Potočnik Slavič 2010; Šmid Hribar 2016; Kladnik, Kruse in Komac 2017). Kulturna pokrajina je rezultat součinkovanja med naravnogeografskimi razmerami in procesi ter človekovimi posegi v preteklosti in sedanjosti (Urbanc 2002). Za Deželo, ravninsko pokrajino na levem bregu Save med Žirovnico in Begunjami, kjer je bilo površje intenzivno ledeniško in rečno preoblikovano (Šifrer 1969; 1992), je značilna mozaična kulturna pokrajina. Pokrajinsko raznolikost tega območja so s sodobnimi metodami dokazali tudi Perko, Hrvatin in Ciglič (2017), ter del Dežele umestili med tako imenovane vroče pokrajinske točke v Sloveniji.

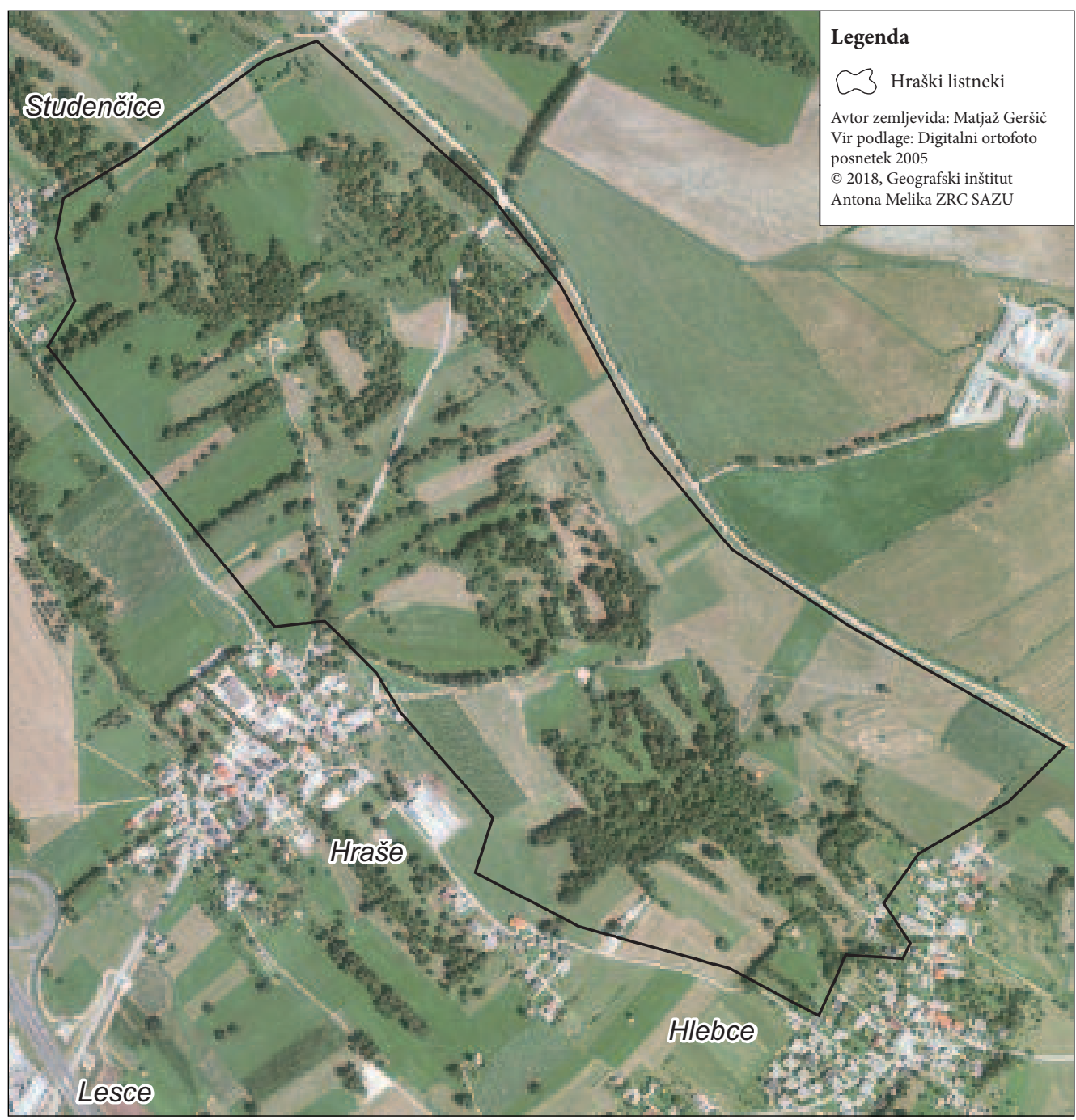

Slika 1: Območje raziskave. 
O raznolikosti kulturnih pokrajin v Sloveniji so v preteklosti pisali predvsem geografi in krajinski arhitekti (na primer Kučan 1998; Urbanc 2002; Perko in Urbanc 2004; Kladnik, Perko in Urbanc 2009). Ti ugotavljajo izjemno pestrost in raznolikost kulturnih pokrajin na Slovenskem ter opozarjajo, da jih je treba ustrezno varovati. Motivi za varovanje in zavarovanje so lahko različni. Med pomembnejšimi je zagotovo skrb za ohranjanje biološke raznovrstnosti, zato varovanje kulturne pokrajine (krajine) predvideva tudi Zakon o ohranjanju narave (1999). Eno takšnih območij, ki so ga naravovarstveniki prepoznali kot vrednega zaščite, so Hraški listneki. Gre za majhno območje med naselji Hraše, Hlebce in Studenčice v občini Radovljica (slika 1).

Z vidika oblikovanosti površja je v širšem kontekstu Dežele na območju Hraških listnekov močne dolgoročne sledi pustila würmska poledenitev. V nasprotju s širšo okolico je ravno na tem območju

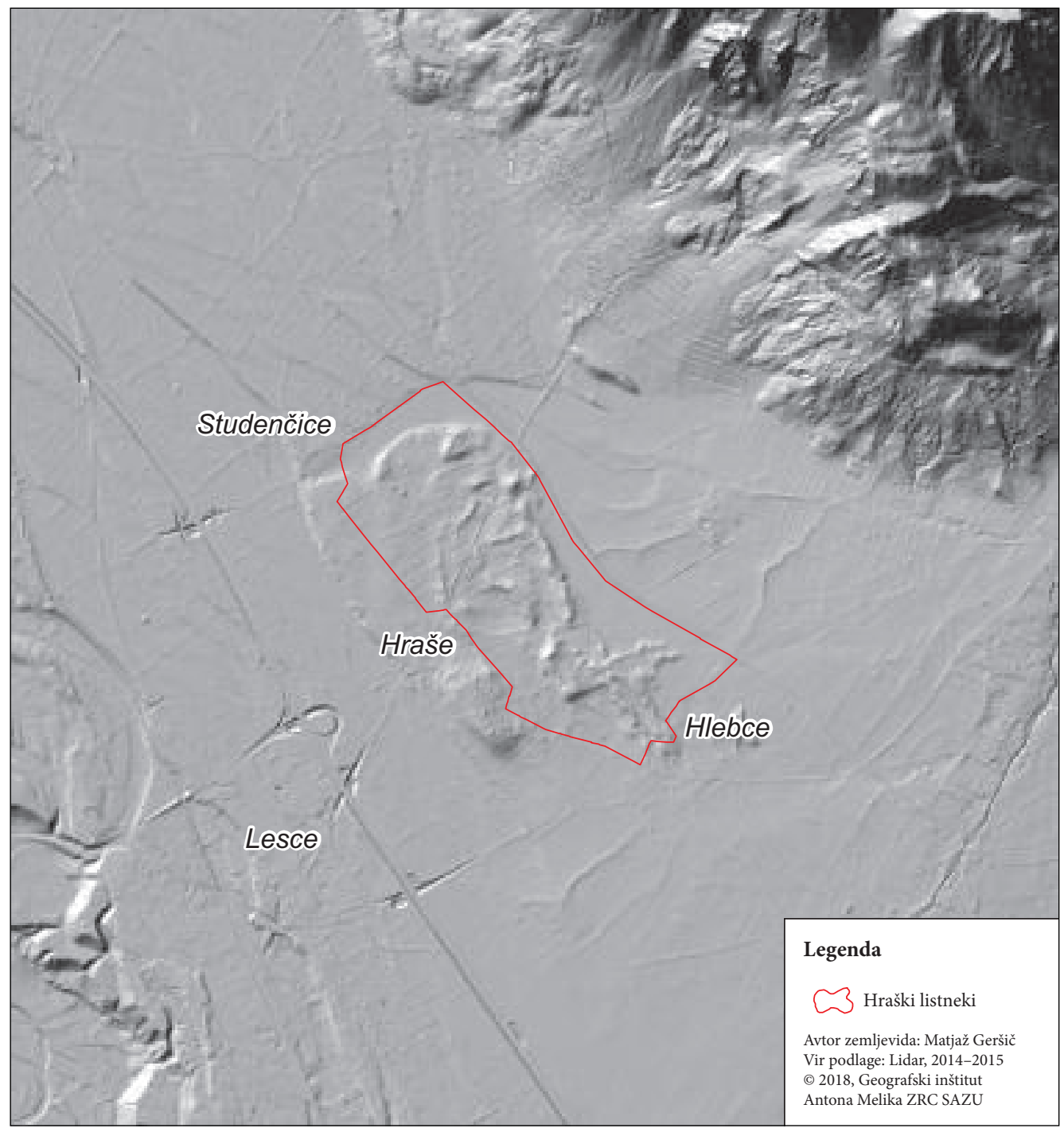

Slika 2: Lidarski prikaz Hraških listnekov na Deželi. 
gostota bočnih morenskih ledeniških nanosov zelo velika. Šifrer $(1969 ; 1992)$ jih je prepoznal kar osem. Večinoma so odloženi na rečno-ledeniških terasah riške poledenitve, na vzhodnem robu pa se stikajo s holocenskim vršajem potoka Zgoša.

Izrazita površinska razgibanost $\mathrm{v}$ primerjavi $\mathrm{z}$ okolico je lepo vidna tudi na lidarskem prikazu tega območja (slika 2).

Za obravnavano območje $\mathrm{z}$ nadmorsko višino dobrih 500 metrov je značilno zmernocelinsko podnebje zahodne in južne Slovenije (Ogrin 1996). Med naravnimi prvinami so v tem delu najmanj izpostavljene hidrološke, omembe vreden je le manjši potok Blatnica v neposredni bližini. V zgodnjem 19. stoletju je pri Studenčicah izviral majši potok Studenčica, za katerega je bilo značilnih nekaj bifurkacij, tekel je predvsem s severa proti jugu ob travnikih in pašnikih (Franciscejski... Hraše 1831, Einleitung $\S 5$; Sinobad 1999, 55).

Na prevladujoči karbonatni matični podlagi so se razvile rendzine, le mestoma je zastopana tudi evtrična rjava prst (Stepančič s sodelavci 1992; Lovrenčak 1998). Potencialna naravna vegetacija na obravnavanem območju je listnati gozd belega gabra in črnega teloha (Helleboro nigri-Carpinetum) (Zupančič, Seliškar in Žagar 1998). Na listavce, predvsem hrast, na tem območju nas opominja tudi ledinsko ime $V$ dobju, ki se pojavlja v franciscejskem katastru in zagotovo označuje nekdanjo prevlado hrasta (Franciscejski... Hraše 1826).

Občina Radovljica je zaradi naravovarstvenega pomena naročila izdelavo Ureditvenega načrta za Hraške steljnike (Ureditveni načrt ... 2014), kakor so zaradi pomembne vloge steljarjenja v dokumentu poimenovali območje, ki ga sicer označuje ledinsko ime Hraški listneki. V želji po sodelovanju z javnostjo in vključevanju lastnikov parcel v odločitve o tem območju, je občina organizirala srečanje in zainteresirani javnosti predstavila predlog ureditvenega načrta, ki so ga na podlagi ideje naravovarstvenikov pripravili sodelavci Zavoda za gozdove Območne enote Bled. Območje je primerno za ekološko in integrirano pridelavo, predvsem sadja, lipovo cvetje pa poleg nekaterih ostalih vrst nudi odlično čebeljo pašo. Med cilji ureditvenega načrta so poudarjene proizvodnje funkcije (ekološka in integrirana pridelava hrane ter malopovršinsko pridobivanje drv), ekološke funkcije (ohranjanje obstoječega stanja poraslosti z gozdom, vzpostavitev mreže debelejšega drevja z dupli) ter socialne funkcije (obujanje starih kmečkih opravil, vzgoja na področju ekologije in ornitologije).

Kmetje, lastniki zemljišč na obravnavanem območju, so se na predlog odzvali zelo negativno in kakršnokoli zaščito tega območja kategorično zavrnili (Rupar 2015).

Vzrok za takšno nestrinjanje lahko pripišemo predvsem zelo strogim omejitvam, ki naj bi veljale za kmetovanje na tem območju. Kmetom je bilo predstavljeno, da bi smeli kositi le enkrat letno, gnojenje ne bi bilo dovoljeno, prav tako ne spravilo lesa z gozdnih zaplat. Kmetje ob gozdnih zaplatah pogosto odlagajo tudi senene bale, kar bi bilo prepovedano. Med motečimi dejavniki, ki negativno vplivajo na okolje Hraških listnekov, elaborat (Ureditveni načrt ... 2014) navaja tudi nelegalne vikend hišice, krčitve gozda (nelegalne), žičnate ograje, intenzivno gnojenje z gnojevko in monokulturnost (prevlada koruze). Opozarja tudi na deponije gnile silaže, silažne folije, pokvarjene krme in gradbenih odpadkov.

O odzivu lastnikov zemljišč so bili na seji, dne 11. junija 2015, obveščeni tudi člani Sveta Krajevne skupnosti Lesce. Ob zavedanju pomembnosti ohranjanja kulturne pokrajine, ki jo predstavljajo Hraški listneki, in poskusu razumevanja kmetovalcev okoliških vasi, so predlagali naslednje ukrepe:

- prepove naj se krčitev gozdnih zemljišč v Hraških listnekih ter planiranje površin; gozdna zemljišča naj se upravlja po načelih prebiralne sečnje, skladno z navodili območne izpostave Zavoda za gozdove; dela naj se izvaja v jesensko-zimskem obdobju;

- izobražuje naj se lastnike in uporabnike zemljišč ter se jih spodbuja k steljarjenju in izdelovanju vejnikov;

- spodbuja naj se trajnostno kmetovanje (tudi čebelarstvo in sadjarstvo);

- odlaganje gnilih bal v gozdni prostor ter nastajanje divjih odlagališč odpadkov naj nadzoruje in kaznuje pristojna inšpekcija;

- prepove naj se gradnjo novih vikendov, za obstoječe pa naj se preveri dovoljenja in ukrepa skladno s predpisi. 
Člani Sveta krajevne skupnosti se ne strinjajo z gradnjo parkirišč v Listnekih ob stari cesarski cesti Vrba-Nova vas pri Lescah ter z izdelavo učne poti (Zapisnik ... 2015). O mnenju krajevne skupnosti je bila širša javnost obveščena tudi prek občinskega glasila (Geršič 2017).

Cilj članka je primerjati temeljne značilnosti rabe tal Hraških listnekov v prvi polovici 19. stoletja, ko so na voljo najstarejši dovolj izčrpni podatki o kmetijskem gospodarjenju, in v zgodnjem 21. stoletju. Tako bomo lahko bolje razumeli, ali obravnavano pokrajino zaznamujejo predvsem ohranjene zgodovinske kategorije rabe tal in prakse rabe naravnih virov ali je v zadnjih dveh stoletjih prišlo do bistvenih sprememb v gospodarjenju z naravnimi viri, zato je treba posebej paziti, da redke živalske vrste iz obravnavane pokrajine ne izginejo.

\section{Metode}

Obseg obravnavane mikrolokacije (sliki 1 in 2) smo povzeli po Ureditvenem načrtu za Hraške steljnike (Ureditveni načrt ... 2014).

Podatki o kmetijstvu v zgodnjem 19. stoletju temeljijo na franciscejskem katastru (Ribnikar 1982; Petek in Urbanc 2004; Drobesch 2009; Golec 2010). V slovenski geografiji skorajšnjo novost predstavlja uporaba cenilnih operatov franciscejskega katastra, namenjenih obdavčitvi zemljišč, ki je v ospredju tega članka. Katastrske cenilne operate sestavljajo cenilni elaborat, njegove priloge, vključno s seznamom kakovostnega razreda vsakega zemljišča in njegove predloge, med drugim vprašalnik o kmetijstvu v katastrski občini. Med najbolj napredne analize podatkov o kmetijskih zemljiščih iz cenilnih operatov franciscejskega katastra sodi študija Krausmanna (2008). Strukturo in vsebino teh virov so na primerih majhnih delov slovenskega ozemlja med drugimi predstavili Verbič (1969), Moritsch (1969), Blaznik (1975), Granda (1994), Trpin (1997), Drobesch (2009), Seručnik (2014), Panjek (2015) in KačičnikGabrič (2016). Za Deželo je vir že uporabil Sinobad (1999), vendar ga je obravnava širšega prostora vodila v izbor podatkov, tako da se je le dotaknil vsebin, ki so predmet naše obravnave; pogrešamo nekoliko bolj kritično uporabo vira. Velika večina informacij v našem članku temelji na arhivskih virih in do sedaj ni bila znana, prav tako nobena med navedenimi študijami ne vsebuje kartografskega prikaza zemljišč po kakovostnih razredih iz zgodnjega 19. stoletja. Za katastrski občini Hraše in Nova vas, ki zajemata vse reliefno razgibano ozemlje Listnekov, smo analizirali cenilni elaborat, njegove predloge in popravke (Franciscejski ... Hraše 1830a; 1830b; 1831; 1837; 1839; Franciscejski ... Nova vas 1830a; 1830b; 1831a; 1831b; 1836; 1837; 1839). Poleg tega smo kartirali tedanje kakovostne razrede posameznih kmetijskih zemljišč na podlagi soočenja katastrskih map (Franciscejski ... Hraše 1826; Franciscejski ... Nova vas 1826) s skupnim zapisnikom zemljiških in stavbnih parcel (Franciscejski ... Hraše ok. 1830; Franciscejski ... Nova vas ok. 1830) ter kategorije rabe tal v izvornem zapisniku zemljiških parcel (Franciscejski ... Hraše 1827; Franciscejski ... Nova vas 1827).

Upoštevanje zgodovinske kritične metode (Winiwarter 2016) pokaže, da se kakovost podatkov različnih sestavnih delov franciscejskega katastra za isto katastrsko občino razlikuje - zaradi različnih metod dela in različnih interesov avtorjev podatkov. Navedbe cenilnega elaborata niso povsem točne in izčrpne, podatki vprašalnika o kmetijstvu pa so v splošnem še bolj pristransko pesimistični. Sinteza vsebin več delov katastra razkriva številne kakovostne informacije, saj podatke sprejema kritično - ob zavedanju metod in motivov nastanka in uporabe virov (Moritsch 1969; Blaznik 1975; Granda 1994; Krausmann 2008). Na podlagi soočenja cenilnih operatov z zemljevidi rabe tal in z zapisniki zemljiških parcel prinaša članek novosti tudi na področju interpretacije najbolj standardne geografske vsebine franciscejskega katastra, to je interpretacije kategorij rabe zemljišč, prikazanih na katastrskih mapah.

Pri kategorizaciji sodobne rabe zemljišč smo za osnovo vzeli podatke iz Evidence dejanske rabe kmetijskih in gozdnih zemljišč (2018) ter na podlagi teh podatkov izrisali zemljevid (slika 7).

Kabinetnemu delu v arhivu je v letu 2017 sledilo terensko delo. To je obsegalo predvsem ogled stanja na terenu, fotografiranje pojavov v pokrajini, kartiranje sodobne rabe zemljišč ter dva nestrukturirana 
razgovora $\mathrm{z}$ domačini o značilnostih kmetijstva $\mathrm{v}$ Hrašah in kmetovanja $\mathrm{v}$ Hraških listnekih danes. Ena od intervjuvank se aktivno ukvarja s kmetijstvom in ji to predstavlja osnovno dejavnost, drugi intervjuvanec je odličen poznavalec krajevne zgodovine in običajev. Intervju smo leta 2017 izvedli tudi v Spodnjem Podjelju z ekstenzivno rejko koz, ki za krmo še uporablja sveže drevesno listje, kar nam je omogočilo bolje razumeti podatke o Hraških listnekih.

\section{Hraški listneki konec 18. in v prvi polovici 19. stoletja}

Že jožefinski vojaški zemljevid iz let 1784-1787 (Rajšp in Serše 1998) (slika 3), na katerem je v osnovnih potezah označena raba zemljišč, prikazuje Hraške listneke - delno kot travinje z drevjem, delno kot njive.

Glavna gospodarska panoga v katastrski občini Hraše v prvi polovici 19. stoletja je bilo kmetijstvo (sliki 4 in 5).

Na področju živinoreje je bila $\mathrm{z}$ vidika rabe naravnih virov Hraških listnekov pomembna velika vloga ovčereje. Po popisu, kjer je bil verjetno spregledan znaten delež živine (primerjaj Granda 1994, 56), so v katastrski občini Hraše okrog leta 1830 gojili 930 ovac, 212 krav in 7 volov, 87 konj in 120 prašičev (Franciscejski... Hraše 1831, Einleitung $\$ 4$ ).

Na podlagi kartiranja tedanjih kakovostnih razredov posameznih travnikov in njiv v Hraških listnekih na parcelni ravni (sliki 4 in 5) ter analize podatkov o značilni rabi vsakega od prisotnih razredov travnikov, pašnikov in njiv ter o značilnih virih krme za posamezne vrste živine prek celega leta (Franciscejski ... Hraše 1830a, 19, 21, 57; 1831, Einleitung $\$ 4, \S 10-11$, Schätzung des Natural Ertrage, $\$ 3-4$,

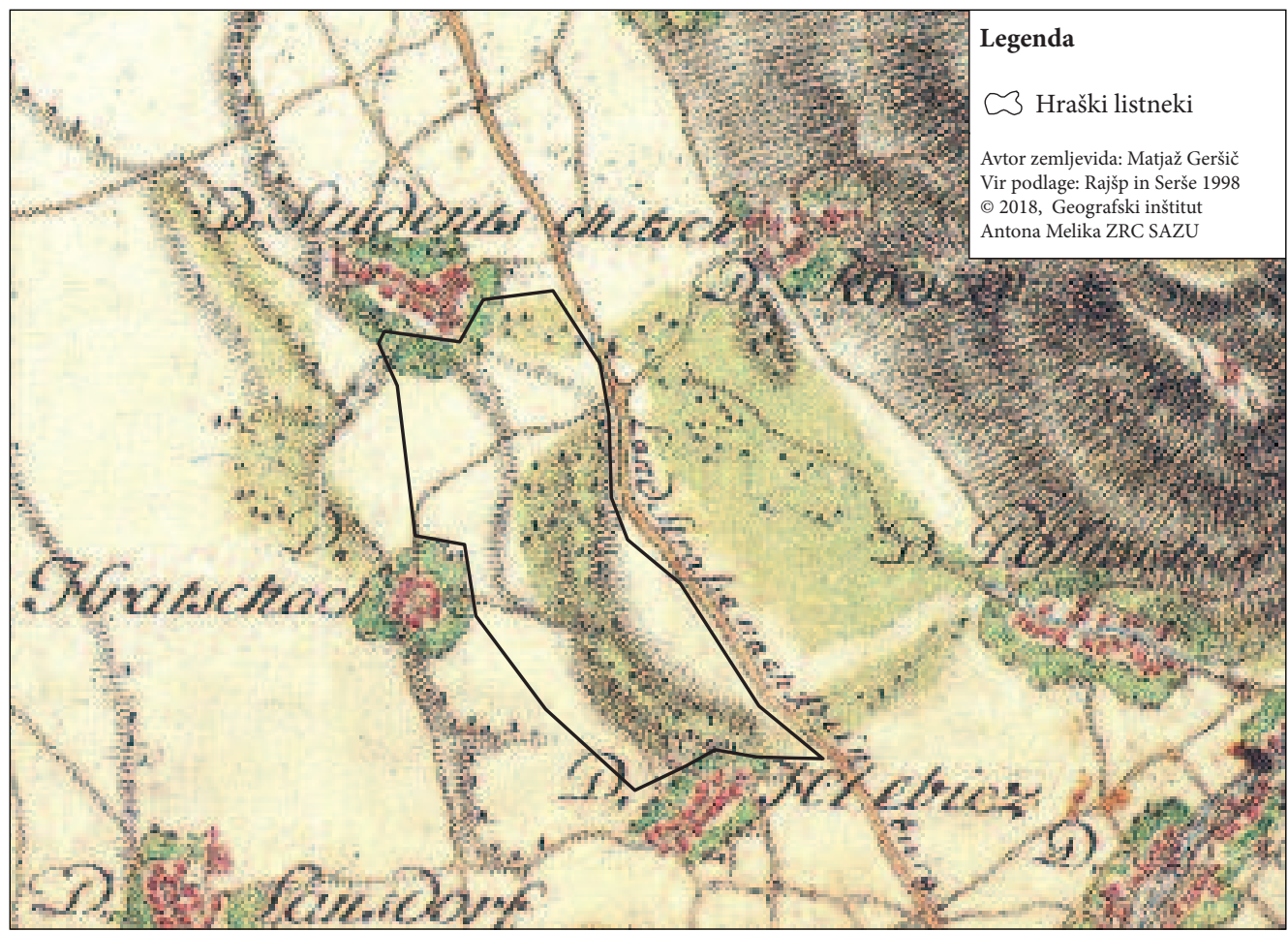

Slika 3: Hraški listneki na jožefinskem vojaškem zemljevidu. 
$\$ 8$, uvezan vir z 20.6.1833; Franciscejski... Nova vas 1830a, 19, 21, 57; 1831a, Einleitung $\$ 4$, Schätzung des Natural Ertrages $\$ 3-6$ ) je postalo jasno, da so Hraški listneki z vidika živinoreje predstavljali:

- pomemben vir sena za govedo in konje ter nezanemarljiv vir otave,

- pomemben vir spomladanske, poletne in jesenske paše,

Legenda
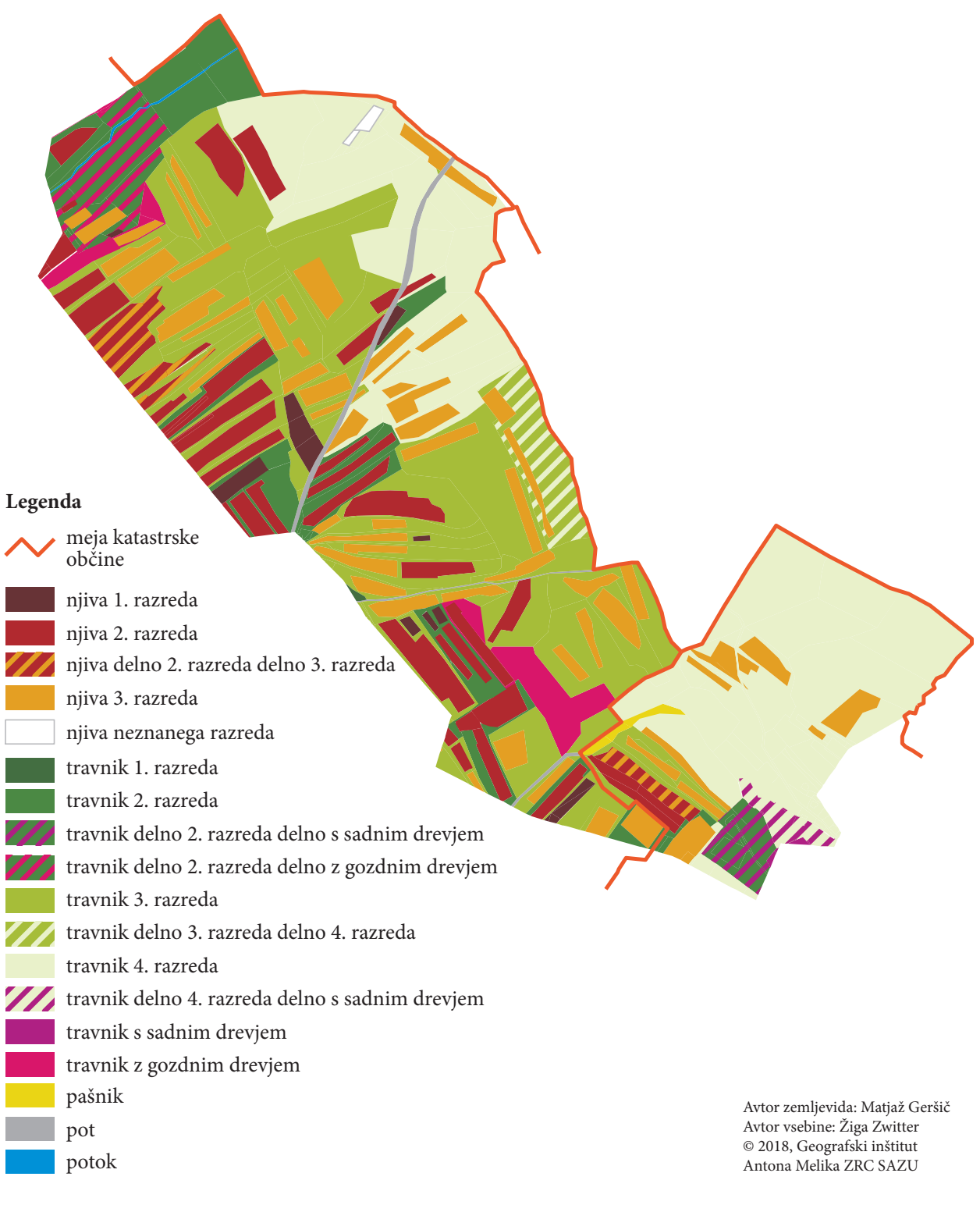

Slika 4: Raba tal in kakovostni razredi zemljišč okoli leta 1830 (Franciscejski ... Hraše 1826; ok. 1830; Franciscejski... Nova vas 1826; ok. 1830). 
- domnevni vir dela trave za poletno krmljenje prašičev ter krme za tiste molzne in delovne živali, ki so bile že tedaj poleti deležne hlevskega krmljenja,

- vir drevesnega listja za zimsko krmljenje ovc,

- vir drevesnega listja za steljo,

- vir njivskih rastlin, pomembnih za živinorejo (na njivah so pridelali del slame, s katero so krmili krave, vole in konje; del krme, ki so jo prašičem dali poparjeno, ajdovih plev in zeljnih listov za prašiče; del krmnih rastlin (detelje za konje in vole; ovsa, ki so ga bili redko deležni konji, repe za prašiče) in nekaj njivskega plevela, ki so ga pozimi pokrmili ovcam).

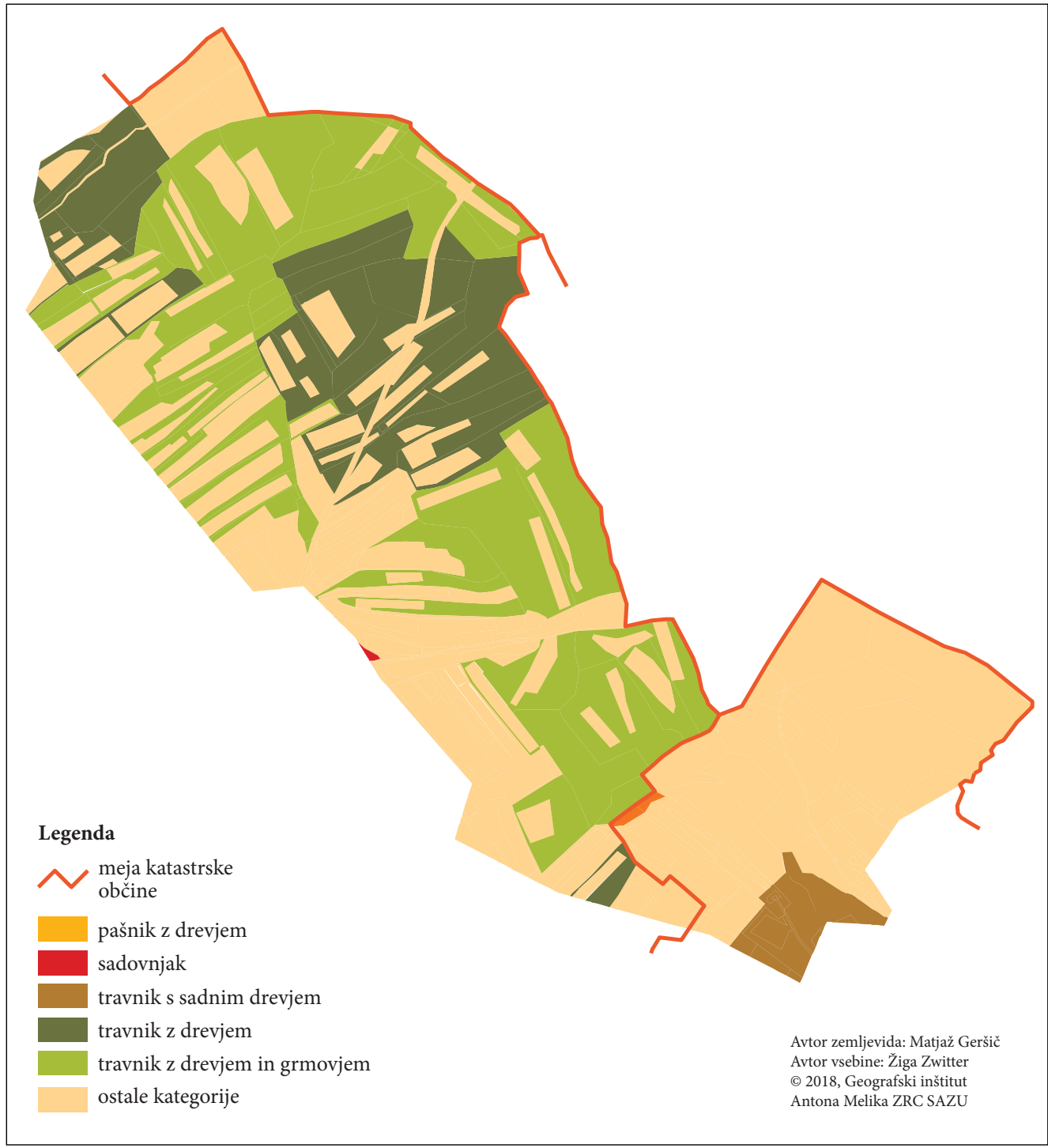

Slika 5: Prisotnost drevja in grmovja na zemljiščih po podatkih izvornega zapisnika zemljiških parcel iz leta 1827 (Franciscejski ... Hraše 1826; 1827; Franciscejski... Nova vas 1826; 1827). 
Od Hraških listnekov neodvisne vire krme in stelje za živino vasi iz katastrske občine Hraše so predstavljali vsaj:

- poletni planinski pašniki, po podatku za katastrsko občino Hraše močno oddaljene ovčje planine, ki so pripadale obravnavanim soseskam na Jelovici in v gorah na jeseniškem območju, kot tudi bližje goveje in konjske planine, kamor so iz katastrske občine Hraše dajali živino na pašo po dogovoru in proti plačilu. Poletna paša na oddaljenih planinah izven katastrske občine je bila značilna tudi za katastrsko občino Nova vas. V kotlini je ostal manjši delež živine iz obeh katastrskih občin - tista, ki so jo potrebovali doma za mleko ali za poljska dela, v planino iz obravnavanih katastrskih občin tudi niso poslali vseh ovc (Franciscejski ... Hraše 1830a, 21, 89; 1831, Einleitung $₫ 4$; Franciscejski ... Nova vas 1830a, 21, 89; 1831a, Einleitung $\$ 4)$;

- večino stelje so v katastrski občini Hraše menda dokupili (Franciscejski ... Hraše 1830a, 19), steljo naj bi dokupovali tudi prebivalci katastrske občine Nova vas (Franciscejski ... Nova vas 1836), vendar podatka nista zanesljiva;

- ostale njive in travniki posestnikov iz katastrske občine Hraše.

Analizirali smo podatke franciscejskega katastra o vseh tipih rabe zemljišč na preučevanem območju v zgodnjem 19. stoletju. Na omejenem prostoru podrobno predstavljamo le rabo travnikov, da bi lahko odgovorili na ključno vprašanje, kaj je v tej sorazmerno tradicionalni pokrajini še podobno rabam iz 19. stoletja, kaj pa se je bistveno spremenilo. Podrobno predstavitev nekdanjega poljedelstva na tem območju izpuščamo, saj so Hraški listneki danes skoraj popolnoma ozelenjeni, delno pa ogozdeni. Pašnike izpuščamo zato, ker so bile njihove površine v Listnekih v času franciscejskega katastra zanemarljive.

\subsection{Travniki v Hraških listnekih v prvi polovici 19. stoletja}

Po kakovosti, izbranih značilnostih rastlinstva in načinu rabe so travnike obravnavanega območja v franciscejskem katastru razdelili v štiri razrede: (1) travnike drugega kakovostnega razreda, (2) travnike tretjega kakovostnega razreda, (3) travnike četrtega kakovostnega razreda in (4) travnike z gospodarsko rabo lesa. Seno so kosili po sredini junija, otavo pa v drugi polovici septembra (Franciscejski ... Hraše 1831, Einleitung $₫ 10$, Schätzung des Natural Ertrages $₫ 4, \S 8$; Fanciscejski ... Nova vas 1831a, Einleitung $₫ 10)$.

Značilnosti in načini rabe ter podrobnosti opisa posameznih kategorij travinja so v splošnem sorazmerno podobni, saj so določali razred obdavčitve, v podrobnostih, ki so pomembne za poznavanje zgodovine Hraških listnekov, pa je prihajalo do razlik (preglednica 1).

Za Hraške listneke je značilna poljska razdelitev na pravokotne grude (Ilešič 1950; slika 6) - njive, ki so običajno pravilne, pravokotne oblike, večinoma na vseh straneh omejuje ozek pas travnika ali pašnika. Parcele so večinoma vzporedne, dostikrat se vlečejo v eni smeri, vendar ni sledu o poljskih skupinah in sistematični odmeri.

Takšna poljska razdelitev ima številne ekološke posledice, tudi z vidika travinja. Zaradi tipa poljske razdelitve so bili v Listnekih v katastrski občini Hraše pogosti ozki travniki med njivami. Kjer je ozek travniški pas ležal neposredno pod robom njive, so ga dosegla hranila s pognojene njive, zato so bili tamkajšnji donosi višji. Učinek je bil lokalno pomemben, saj v katastrski občini Hraše v prvi polovici 19. stoletja travnikov niso gnojili (Franciscejski... Hraše 1831, Einleitung $\$ 10$, Schätzung des Natural Ertrages $\$ 4$ ). Slika 4 dokazuje, da so najboljši travniki Hraških listnekov običajno ležali ob slabo zastopanih njivah prvega in ob mnogo obsežnejših njivskih zemljiščih drugega kakovostnega razreda. Slednje so pognojili v treh petinah let, v nasprotju z njivami tretjega kakovostnega razreda, pognojenimi le v dveh petinah let (Franciscejski ... Hraše 1831, Schätzung des Natural Ertrages $₫ 3$ ). Vendar navedeni proces dotoka hranil na travnike ni bil splošna značilnost travnikov drugega kakovostnega razreda v Hraških listnekih - primeri takšnih travnikov, ki mnogo presegajo ozke robove ob njivah, dokazujejo, da je na njihovo kakovost močno vplivala naravno boljša rodovitnost prsti.

Cel sklop pomembnih ekoloških posledic poljske razdelitve na pravokotne grude je povezan z grmovjem in drevjem, ki mestoma raste na številnih med ozkimi, delno travnatimi parcelnimi mejami. 
Preglednica 1: Raba in bistvene značilnosti travnikov v Hraških listnekih v prvi polovici 19. stoletja (datumi paše so podani na ravni katastrske občine, ne na ravni posameznih razredov zemljišč) (Franciscejski ... Hraše 1830a, 57; 1830b; 1831, Einleitung $\$$ 9, Schätzung des Natural Ertrages $\$ 4$, $\$$ 8, uvezan vir $z$ 20. 6. 1833; 1837; 1839; Franciscejski... Nova vas 1830a, 57; 1830b; 1831a, Einleitung $\$ 9$, Schätzung des Natural Ertrages $\$ 4, \$ 5, \$ 6 ; 1831 b$; 1836; 1837; 1839).

\begin{tabular}{|c|c|c|}
\hline kategorija & katastrska občina Hraše & katastrska občina Nova vas \\
\hline travniki 2. razreda & $\begin{array}{l}\text { - } 2 \text { košnji ter skromna jesenska paša; } \\
\text { - sladka krma; } \\
\text { - manj sena in otave kot na travnikih } \\
\text { 1. razreda }\end{array}$ & $\begin{array}{l}\text { - } 2 \text { košnji ter paša; } \\
\text { - sladka krma; } \\
\text { - manj sena in otave kot na travnikih } \\
\text { 1. razreda }\end{array}$ \\
\hline travniki 3. razreda & $\begin{array}{l}\text { - spomladanska paša do } 1 \text {. maja, } \\
1 \text { košnja ter paša po košnji; } \\
\text { - sladka krma; } \\
\text { - travna ruša redka, rastline v primerjavi } \\
\text { z bolj kakovostnimi travniki nizke }\end{array}$ & $\begin{array}{l}\text { - } 1 \text { košnja, paša od 10. 8. do pozne } \\
\text { jeseni; spomladanska paša je doku- } \\
\text { mentirana v predlogi, iz čistopisa } \\
\text { je verjetno pomotoma izpadla; } \\
\text { - sladka krma }\end{array}$ \\
\hline travniki 4. razreda & $\begin{array}{l}\text { - spomladanska paša do } 1 \text {. maja, } \\
1 \text { košnja ter paša po košnji; } \\
\text { - sladka krma; } \\
\text { - slabo rodovitni sušnejši travniki } \\
\text { z redko rušo, dobro zastopano trdo } \\
\text { rastlinje z nizko krmno vrednostjo }\end{array}$ & $\begin{array}{l}\text { - spomladanska paša do konca aprila, } \\
1 \text { košnja ter paša od 10. 8. do pozne } \\
\text { jeseni; } \\
\text { - posestniki so spravili seno, pašno } \\
\text { pravico spomladi in jeseni pa so } \\
\text { imeli kmetje iz drugih srenj; } \\
\text { - sladka krma; } \\
\text { - rastlinje je redko, kratko, slabo } \\
\text { kalorično; } \\
\text { - ponekod malo poraščeni z grmovjem }\end{array}$ \\
\hline $\begin{array}{l}\text { travniki z gozdnim } \\
\text { drevjem }\end{array}$ & $\begin{array}{l}\text { - sestava: } 3 / 4 \text { travnika }+1 / 4 \text { listavcev } \\
\text { (vsaj hrast ter bukev in verjetno } \\
\text { jesen); } \\
\text { - predloga omenja obsekavanje drevja, } \\
\text { posledično so nastala številna dupla; } \\
\text { - ocena travniškega donosa: } 95 \% \\
\text { donosa travnikov } 3 \text {. razreda }\end{array}$ & l \\
\hline $\begin{array}{l}\text { travniki s sadnim } \\
\text { drevjem }\end{array}$ & l & $\begin{array}{l}\text { - sestava: } 3 / 4 \text { travnika, podobnega } \\
\text { 2. razredu (nekoliko izdatnejši) + } \\
\text { 1/4 sadovnjaka; } \\
\text { - negotovo: } 1 \text { ali } 2 \text { košnji ali pa so } \\
\text { travinje uporabljali le kot pašnik; } \\
\text { - drevje: slive, jablane, orehi, nekaj } \\
\text { hrušk }\end{array}$ \\
\hline pašniki & 1 & $\begin{array}{l}\text { - sladka krma; } \\
\text { - v splošnem precej slabši od travnikov } \\
\text { 4. razreda }\end{array}$ \\
\hline
\end{tabular}




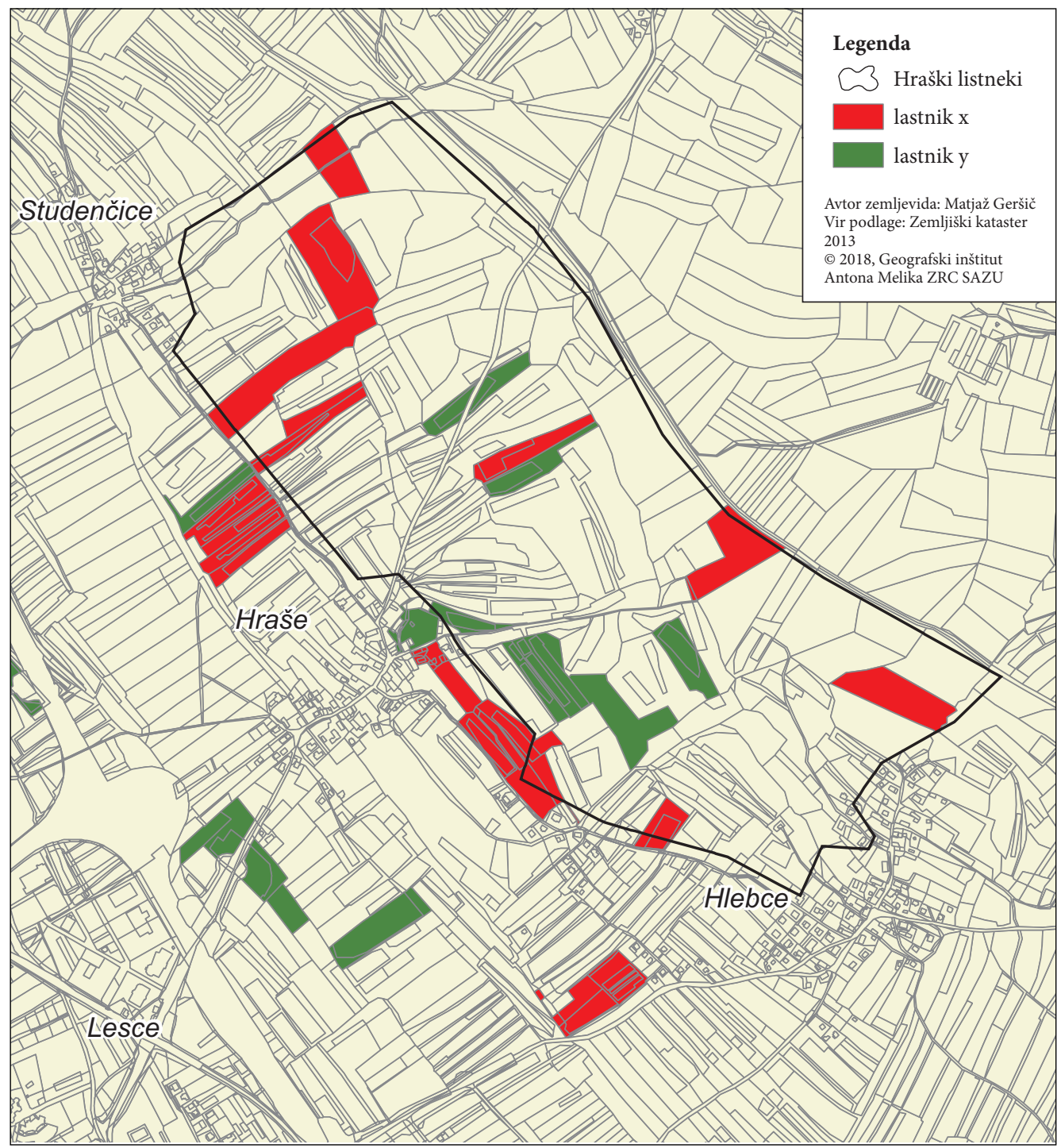

Slika 6: Poljska razdelitev na pravokotne grude na obravnavanem ozemlju leta 2013.

\section{2 Mejice ter travinja $\mathrm{z}$ drevjem (in grmovjem) v Hraških listnekih v prvi polovici 19. stoletja}

V Sloveniji je $1 \%$ zemljišč, ki so bile v franciscejskem katastru označene kot travnik z gozdnim drevjem in mestoma tudi z grmovjem (v preglednicah rabe zemljišč po posameznih katastrskih občinah v pisnem delu franciscejskega katastra) (Gabrovec in Kumer 2019), naša analiza pa opozarja na metodološke izzive prepoznavanja travinja $\mathrm{z}$ drevjem $\mathrm{v}$ zapisnikih in na zemljevidih franciscejskega katastra.

Metodološko pomembna je primerjava dokumentiranja drevja in grmovja v Hraških listnekih na franciscejski katastrski mapi, v originalnem franciscejskem zapisniku zemljiških parcel (slika 5) in v pre- 
delanem zapisniku, ki vsebuje podatke o kakovostnih razredih na ravni parcel (slika 4). Tako iz kartografskega dela katastra, ki je bil izrisan in preverjen na terenu (Ribnikar 1982) kot iz originalnega zapisnika zemljiških parcel je očitno, da so travniki z drevjem v zgodnjem 19. stoletju zavzemali obsežne površine Hraških listnekov (slika 5). Takšno stanje se ujema s sumarijem zemljišč, ki so jih na ravni katastrske občine zavzemale posamezne kategorije rabe tal, saj ta v katastrski občini Hraše dokumentira obsežna zemljišča travnikov z drevjem (Sinobad 1999, 56). Podatke o drevju dopolnjuje opis v Hraških listnekih dobro zastopanih njiv drugega kakovostnega razreda, ki trdi, da so te njive pogosto ležale med travniki z gozdnim drevjem (Franciscejski... Hraše 1831, Schätzung des Natural Ertrages $\$ 3$ ). Vendar je drevje v Hraških listnekih očitno le izjemoma dosegalo formalno predpisano pokrovnost, $s$ katero so $\mathrm{v}$ katastrski občini Hraše za potrebe obdavčitve opredelili travnik $\mathrm{z}$ gozdnim drevjem (preglednica 1), zato se je v realnosti prisotno divje drevje na travnikih ter ob mejah travnikov in njiv $v$ Listnekih skoraj povsem izmuznilo iz podatkov o rabi tal $v$ le par let mlajšem, za potrebe obdavčitve dodelanem zapisniku zemljiških parcel (slika 4; Sinobad 1999, 56).

Širšega metodološkega pomena za raziskave franciscejskega katastra je tudi podatek, da so bili v katastrski občini Nova vas travniki četrtega kakovostnega razreda v ledini Blato na jugovzhodu Hraških listnekov ponekod malo poraščeni z grmovjem (Franciscejski ... Hraše 1831, Schätzung des Natural Ertrages $₫ 4$ ), kar ni prikazano niti na kartografskem delu katastra niti v nobenem od zapisnikov zemljiških parcel (sliki 4 in 5). Odsotnost grmovja s franciscejskih katastrskih zemljevidov in zapisnikov torej ne dokazuje popolne odsotnosti grmovja na tedanjem terenu. Drevje je kartirano tudi na travniški parceli severno od pašnikov (Franciscejski ... Nova vas ... 1826), kjer ga ne označuje noben zapisnik zemljiških parcel (Franciscejski ... Nova vas 1827; ok. 1830).

Ker so bili gozdovi precej oddaljeni od vasi na obrobju Hraških listnekov, je bilo drevje in grmovje mejic in travnikov Hraških listnekov (slika 5) zelo pomemben vir stelje. Lokalna količina stelje ni zadoščala, z njo so se oskrbovali tudi v sosednjih katastrskih občinah. Listje hrastov, jesenov in bukev, ki so rasli na travnikih z gozdnim drevjem, so uporabljali za steljo in ovčjo krmo (Franciscejski ... Hraše 1830b; 1831, Einleitung $\$ 4$, Schätzung des Natural Ertrages, uvezan vir z 20.6.1833) - glede na etnološke podatke s slovenskega ozemlja gotovo vsaj delno v obliki vejnikov. Redno so torej obsekavali drevje, da so olistane veje z mladim listjem posušili za zimsko krmo (Ifko 2011). Ponekod v Evropi je sicer dokazano tudi smukanje listja za krmo z rastočega drevja - torej pridobivanje krme brez sečnje, poleg tega so porabili tudi listje drevja, ki so ga celega posekali. Kot krma v obdobjih pomanjkanja pa je bilo uporabno celo odpadlo jesensko listje, če je bilo vreme suho in mrzlo. Hrast, bukev in jesen, ki jih tu dokumentira franciscejski kataster, so drevesa, katerih listje so tradicionalno uporabljali za krmo (Emanuelsson 2009, 156-157, 196-199, 201, 204). Steljarjenje se je v Hraških listnekih lepo dopolnjevalo $\mathrm{z}$ običajnim spomladanskim čiščenjem travnikov, ki je mdr. vključevalo odstranjevanje listja, ki je na travnike padlo z drevja in grmovja (Franciscejski ... Hraše 1830a, 51, 59; 1831, Einleitung $\$ 10$; Franciscejski ... Nova vas 1830a, 19, 51; 1831a, Einleitung $\$ 10)$. Jeseni so tako zaradi steljarjenja že opravili del dela, ki bi sicer počakalo na pomlad.

Tudi z vidika oskrbe z lesom je bilo drevje v Hraških listnekih priročno blizu. Vendar pa so posestniki iz katastrske občine Hraše posedovali tudi gozdove na Jelovici v katastrski občini Lancovo, menda tudi v katastrski občini Doslovče ob Zelenici (Franciscejski ... Hraše 1830a, 73; 1831, Einleitung $\$ 10$ ), posestniki iz katastrske občine Nova vas pa so se z gozdnimi viri oskrbovali v gozdu pri Dvorski vasi (Franciscejski... Nova vas 1830a, 83).

Zgodnjenovoveške napol odprte agrarne pokrajine, kakršna je bila v Hraških listnekih v času franciscejskega katastra, so nudile ustrezne habitate za malo divjad (Kolar 2012; Zwitter 2014, 628). V krošnjah dreves, ki so jih obsekavali za krmo, so živeli organizmi, ki danes težko najdejo ustrezne habitate: v krošnjah takšnih dreves so svoja zatočišča (dupla) in hrano našle različne vrste ptic, netopirjev in žuželk; trohnenje manjših delov obsekavanih dreves je ustvarjalo habitate za nekatere hrošče in glive; na takšnem drevju so rasle na primer nekatere vrste lišajev, mahov in bela omela. Za travnike z drevjem, še posebej tiste, kjer med drevjem prevladuje jesen, je poleg tega značilno izjemno visoko število 
deževnikov, v njihovih rovih pa živijo mikroorganizmi, ki vežejo dušik in z njim bogatijo prst. Pas grmovja in drevja je posevke po eni strani varoval pred vetrom, predstavljal vir kurjave in lesa za ograjevanje obdelovalnih zemljišč pred živino na paši ter nekaterih užitnih plodov (Emanuelsson 2009, 199, 204; Kolar 2012), po drugi strani je drevesna senca zavirala rast poljščin (Franciscejski ... Hraše 1831, Einleitung $\$ 10$ ), a hkrati blažila nevarnost suše (Zwitter 2019). Ugoden vpliv vrst iz drevja na mikroklimo se pokaže tudi ob blaženju temperaturnih nihanj in vpliva mraza pozimi (Kolar 2012, 226-227).

\section{Hraški listneki na začetku 21. stoletja}

V Hrašah, kjer živi večina kmetov s posestjo v Hraških listnekih, je devet kmetij, kjer se vsaj deloma še ukvarjajo s kmetijstvom, prevladuje živinoreja (preglednica 2).

Preglednica 2: Stalež živine v Hrašah spomladi leta 2017 (Muhovec 2018).

\begin{tabular}{ll} 
kmetija & vrsta živine, število glav \\
\hline 1 & ovce, 5 \\
2 & konji, 12 \\
3 & govedo, 30 \\
4 & govedo, 5 \\
5 & govedo, 150 \\
6 & govedo, $6 ;$ konj, 1 \\
7 & govedo, 250 \\
8 & govedo, 27 \\
9 & koza, 1 \\
\hline
\end{tabular}

Večino živine predstavljajo krave, rejene za prirejo mleka. Na štirih kmetijah se vsaj en delovno aktiven član gospodarstva ukvarja izključno s kmetijstvom. Mleko odkupujejo zadruge in ga izvažajo v Italijo. Dopolnilne dejavnosti na kmetijah v Hrašah so redke. Na eni izmed njih imajo elektrarno, nekaj je prenočitvenih zmogljivosti, le na eni del mleka sami predelujejo v končne izdelke (jogurt, skuta). Med bolj ekološkimi proizvodi lahko najdemo zgolj seneno mleko. To je mleko krav, ki ne jedo silaže in močnih krmil. Poleti se prosto pasejo, pozimi pa so hranjene izključno s senom. Za steljo manjši kmetje uporabljajo predvsem slamo in žaganje. Le na dveh kmetijah uporabljajo listje, na dveh, največjih kmetijah, pa stelje ne uporabljajo več, saj so hlevska tla sestavljena iz rešetk. Tisti, ki še uporabljajo listnato steljo, listje nagrabijo kar z obračalniki. Živina se redko pase, izjema je le nekaj goveda, ki se poleti pase v okolici kmetij, in drobnica (ovce), ki se čez poletje pase na planini. Izjemoma se v Hraških listnekih pase tudi živina kmetov od drugod, ki zemljišča za pašo najamejo (slika 10).

Vsi sedanji kmetje iz Hraš obdelujejo tudi parcele, ki so na območju Hraških listnekov. Raba zemljišč na tem območju je zelo raznolika. Prevladujejo trajni travniki.

Gozdove in mejice obravnavanega območja danes prerašča gozdna združba predalpskega nižinskega gozda hrasta gradna in belega gabra s trilistno vetrnico (Hacquetio-Carpinetum var. Anemone trifolia), gozdnatost je $20 \%$. Med gozdnim drevjem prevladujejo lipa (Thilia platyphyllos) in lipovec (Tilia Cordata) (65\%), hrasti (25\%), iglavcev je $5 \%$. Grmovna plast je ponekod slabše razvita, ker še vedno poteka steljarjenje (Ureditveni načrt... 2014).

Pestrost ptičjih vrst je precejšnja. Zanimive so predvsem vrste, ki na tem območju redko gnezdijo, na primer močvirska trstnica (Acrocephalus palustris) (Geršič 1998). Posebno pozornost pa ornitologi namenjajo ogroženim vrstam, na primer navadni postovki (Falco tinnunculus), zeleni žolni 
(Picus viridis), sivi žolni (Picus canus) in velikemu skoviku (Otus scops). Ostale prepoznane ogrožene gnezdilke v Hraških listnekih so brglez (Sitta europaea), lesna sova (Strix aluco) in kratkoprsti plezalček (Certhia brachydactyla) (slika 8) (Kozinc 2016; Mulej 2016).

$\mathrm{Z}$ vidika ptic duplaric je vrstna sestava gozdnih zaplat v Hraških listnekih izrazito ugodna. Predvsem lipa ima mehak les, hrast pa dolgo življenjsko dobo in debelejša debla ter posledično globlja dupla. Drevje zaradi obsekovanja ter raznih naravnih pojavov (vetrolom, žledolom) mestoma začne gniti in tako se ustvarjajo dupla različnih velikosti.

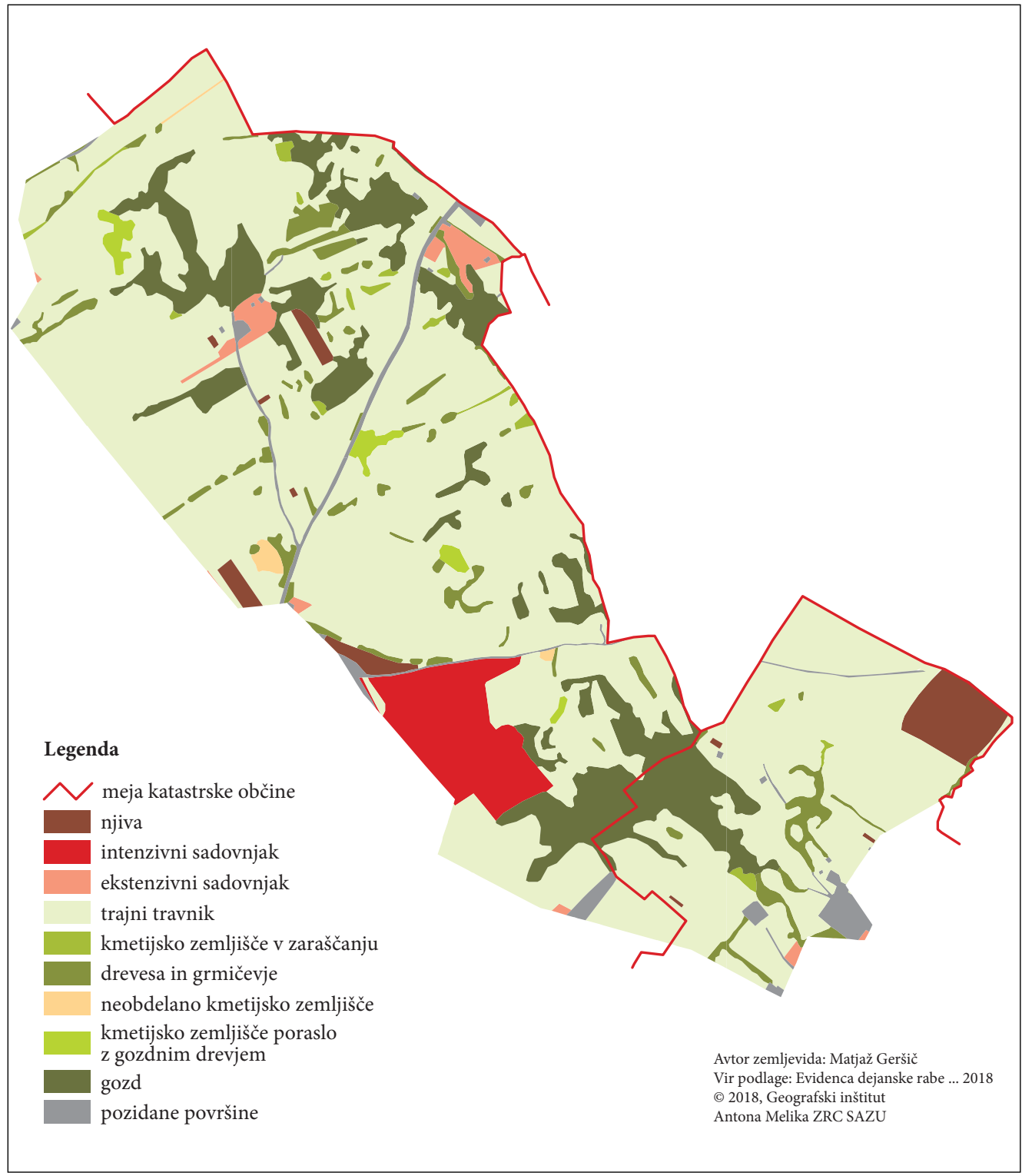

Slika 7: Sodobna raba zemljǐ̌č v Hraških listnekih. 


\section{Spremembe kulturne pokrajine ter kmetijstva med prvo polovico 19. stoletja in zgodnjim 21. stoletjem}

Od zgodnjega 19. stoletja do danes so se nekateri elementi kulturne pokrajine Hraških listenkov ohranili, nekateri pa so se spremenili. Prevladujoči proces, ki je zajel spreminjanje njiv Hraških listnekov, je ekstenzifikacija, saj so nekdanje njive danes v veliki meri ozelenjene, kar še posebej velja za tiste v notranjosti obravnavane pokrajine. Ogozduje se del nekdanjih travnikov najslabšega kakovostnega razreda na severovzhodu Hraških listnekov in nekdanja obdelovalna zemljišča v osrčju obravnavane pokrajine vzhodno od Hraš. Izjemoma so v delu neposrednega jugovzhodnega zaledja Hraš njive in nekdanje travniških pasove, ki so ločevali posamezna polja, spremenili v intenzivne sadovnjake.

Poleg sprememb kategorij rabe tal je prišlo do bistvenih sprememb načinov gospodarjenja $z$ obravnavanimi zemljišči. Na večini kmetij so klasično steljarjenje in izdelovanje vejnikov izvajali do okoli leta 1950 (Rezar 2018). Ker stelje in vejnikov kmetje večinoma ne potrebujejo več (hlevi brez stelje in steljarjenje z žaganjem), se tovrstnih tradicionalnih oblik gospodarjenja ne izvaja več. Košnja sena je danes odvisna predvsem od intenzivnosti kmetovanja. Največja hraška kmeta kosita petkrat. Prvič že aprila, zadnjič pa oktobra ali novembra. Pri gnojenju travnikov uporabljata umetna mineralna gnojila. Ostali, manjši kmetje gnojijo s hlevskim gnojem in gnojevko, travnike pa kosijo trikrat, maja, julija in oktobra. V Hraških listnekih je še danes močno prisotno travinje z gozdnim drevjem in grmovjem, močno spremenjena pa je raba teh zemljišč. Košnja se $\mathrm{v}$ vseh primerih začne prej in tudi kosijo večkrat kot v zgodnjem 19. stoletju. Posledica dodajanja gnojil je deloma spremenjena vrstna sestava. Nekatere vrste divjadi, generalisti (na primer lisica, kuna belica) se na spremembe kulturne pokrajine uspešno prilagajajo, medtem ko številčnost specialistov (na primer poljski zajec, poljska jerebica, gozdne kure) zaradi okoljskih sprememb naglo upada (Kolar 2012, 223). Ogroženost redkih vrst je tudi glavni motiv, ki je naravovarstvenike vodil k ideji o zavarovanju obravnavanega območja. Gre predvsem za pestrost redkih ptičjih vrst, ki imajo na tem območju ugodne pogoje za gnezdenje. Za velikega skovika (Otus scops) na primer velja, da je sicer splošno razširjena, ekološko specializirana vrsta, vendar se njegov gnezditveni habitat v Sloveniji vidno krči. Na Gorenjskem je njegovo gnezdenje sploh neredno in izredno redko. Po najnovejših podatkih obstanek vrste v Sloveniji ni verjeten, v kolikor bodo dejavniki ogrožanja delovali še naprej. Podobno velja za zeleno žolno. Do krčenja habitata prihaja predvsem zaradi opuščanja tradicionalnega kmetovanja in intenzifikacije kmetijstva, onesnaževanja ter drugih vzrokov. Navadna postovka (Falco tinnunculus), zelena žolna (Picus viridis) in siva žolna (Picus canus) so bile v preteklosti v Sloveniji splošno razširjene, v sodobnosti pa populacije zaskrbljujoče nazadujejo in prostorsko izginjajo. Vzroki so podobni kot pri velikem skoviku, pri navadni postovki se pojavlja tudi nezakoniti lov, sivo žolno pa omejujeta intenzivna sečnja in gozdne monokulture (Bračko s sodelavci 1994; Pravilnik o uvrstitvi ... 2002). Pri tem ne smemo spregledati, da se je vrstna sestava gozdnih sestojev od zgodnjega 19. stoletja, kot vse kaže, precej spremenila - danes je več lipe in lipovca, manj pa jesena in bukve; hrast je bil dobro zastopan v obeh časovnih presekih.

Intenzifikacija kmetijstva je mestoma tako agresivna, da dramatično spreminja podobo kulturne pokrajine. Zaradi opuščanja steljarjenja $\mathrm{v}$ zadnjih letih ter višjih proizvodnih stroškov na razgibanem površju prihaja do podiranja drevja, strojnega ruvanja drevesnih štorov in izravnavanja razgibanega površja, saj je kmetijstvo na delu obravnavane pokrajine intenzivno (slika 9).

Močan upad števila aktivnih kmetij z zemljišči v Hraških listnekih je zaskrbljujoč, saj je kmetijstvo v dolgi zgodovini bistveno sooblikovalo obravnavano kulturno pokrajino. Dodaten razlog za skrb predstavlja dejstvo, da se kmetiji, ki redita največ živine, ukvarjata z intenzivno govedorejo. Petkratna košnja in gnojenje travnikov $\mathrm{z}$ umetnimi gnojili temeljito spreminjata habitate Hraških listnekov in povzročata upad biološke raznovrstnosti. Kmetijske rabe različnih zemljišč Hraških listnekov so danes mnogo

Slika 8: Nekatere prepoznane gnezdilke v Hraških listnekih (A: veliki skovik, B: navadna postovka, C: siva žolna, D: zelena žolna, E: brglez, F: lesna sova, G: kratkoprsti plezalček. 


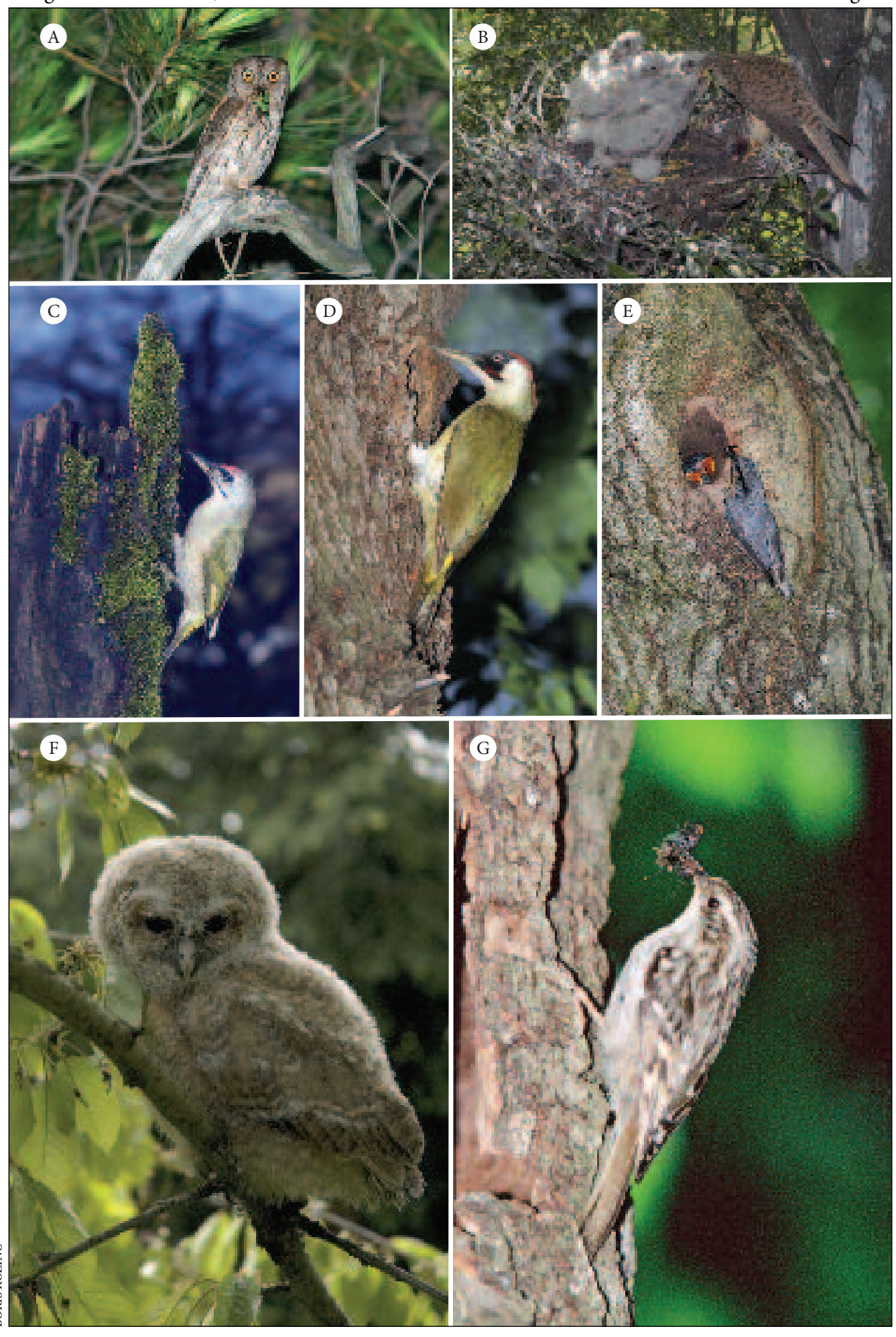


bolj raznolike, kot so bile v zgodnjem 19. stoletju, saj združujejo tako intenzivno obdelane parcele velikih živinorejcev kot mnogo bolj trajnostno rabo nekaterih manjših živinorejcev, a tudi številna opustela zemljišča, kjer se je kulturna pokrajina bistveno spremenila ali pa je močno spreminjanje v teku. Vendar pa tako intenzifikacija kot opuščanje kmetovanja vodi k zmanjšanju biološke raznovrstnosti in propadu tradicionalno mozaične kulturne pokrajine. Kmetijska raba nobenega od tipičnih travišč v Hraških listnekih danes ni več enaka kot v zgodnjem 19. stoletju: izginila je nekdaj močno razširjena spomladanska paša na travnikih, skoraj opuščena je jesenska paša. Ni več negnojenih travnikov, nikjer na tipičnih zemljiščih ne kosijo le enkrat ali dvakrat. Kljub temu prisotnost redkih vrst dokazuje, da še nismo zamudili priložnosti, da z bolj trajnostnimi kmetijskimi praksami ohranimo pomembno naravno in kulturno dediščino. Dejstvo, da v Hrašah samo ena kmetija sama predeluje mleko, s čimer ustvarja višjo dodano vrednost - a še ta ne cilja na pomembno tržno nišo ekoloških proizvodov - dokazuje, da lokalni kmetje še niso dovolj razmislili o ekonomskih prednostih, ki bi jim jih trajnostna raba Hraških listnekov lahko prinesla. Trajnostna raba bi bila za kmete ekonomsko upravičena zgolj v primeru ustrezne kmetijske politike. Nasveti, ki so jih kmetje prejeli s strani skupine, ki bi Hraške listneke rada zavarovala, niso bili vsi dovolj premišljeni. Takšen primer je v uvodu članka navedeni predlog, naj se uporabnike zemljišč spodbuja k izdelovanju vejnikov. Porezane veje nekaterih dreves s svežim listjem v današnjem tradicionalnem kmetovanju veljajo za poslastico za koze (Smukavec 2017), posušeno listje je lahko pomemben vir zimske krme drobnice. Problem je v tem, da te na obravnavanem območju skoraj ni več, za govedo pa so vejniki postranskega pomena, krma goveda zgolj z vejniki ni mogoča (Emanuelsson 2009, 157, 196, 198).

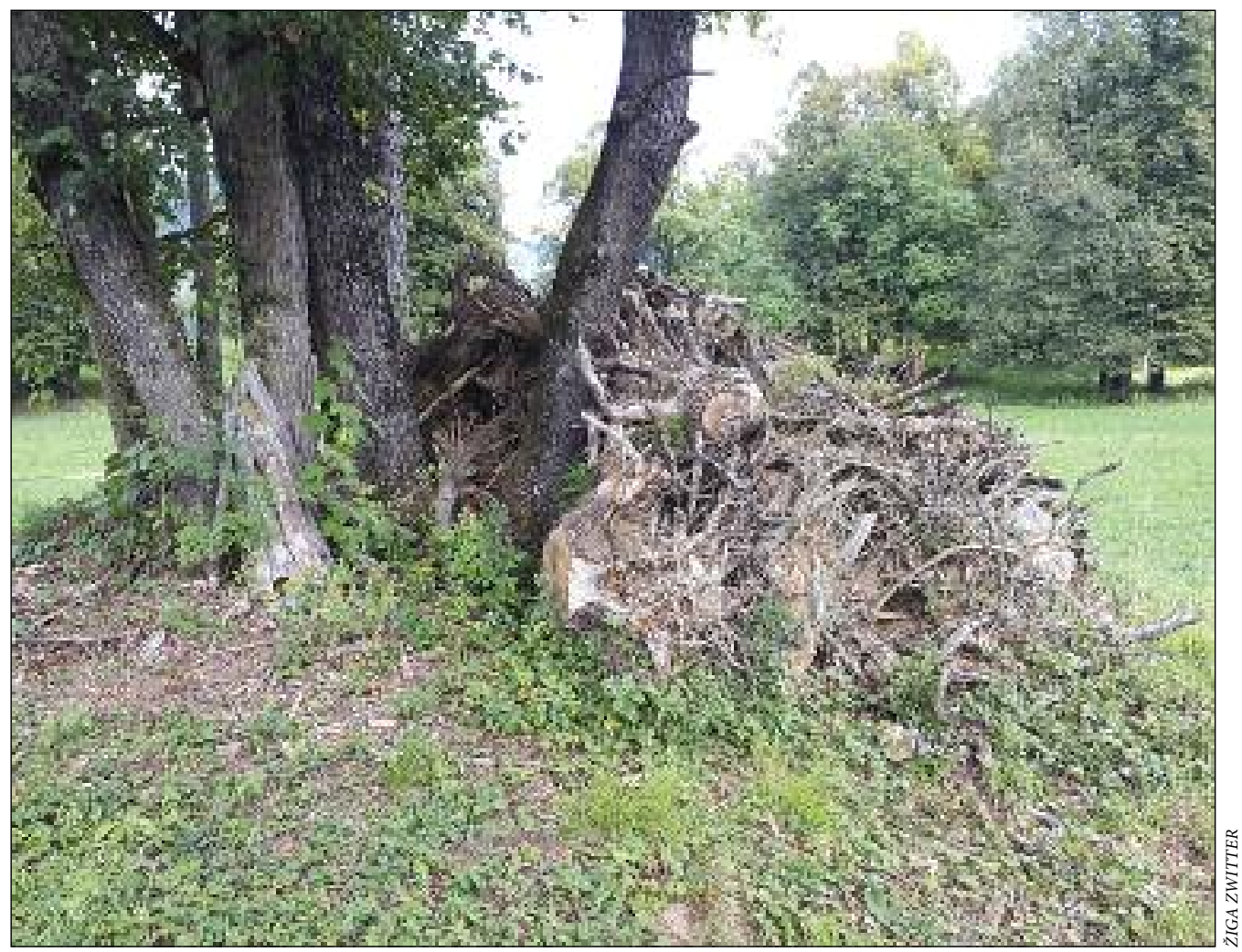

Slika 9: Spreminjanje kulturne pokrajine Hraških listnekov z uporabo sodobne mehanizacije. 


\section{Sklep}

Na podlagi analize izbranih virov in stanja na terenu lahko ugotovimo, da Hraški listneki predstavljajo zanimivo kulturno pokrajino, ki so jo kmetje iz okoliških vasi s tradicionalnim kmetovanjem ustvarili in skozi stoletja ohranjali ali preoblikovali raznovrstne habitate. Interes širše skupnosti bi moral biti, da se ta proces, ki ga ogrožata tako intenzifikacija kot opuščanje kmetijskih zemljišč, ne prekine, saj takšna pokrajina nudi priložnosti za trajnostno kmetijstvo ter ekološko in integrirano pridelavo, ki je okolju prijaznejša in vse bolj cenjena ter hkrati ohranja naravno in kulturno dediščino. Če na tamkajšnjo kulturno pokrajino gledamo le od daleč, se zdi sodobno stanje podobno kot v preteklosti, če pa primerjamo biološko raznovrstnost, lahko sklenemo, da spremenjena raba lahko usodno vpliva na vrstno sestavo.

Predstavljeni ukrepi za zaščito Hraških listnekov dokazujejo, da bo tamkajšnjo biotsko raznovrstno kulturno pokrajino lahko ohranil le bolj celovit pristop. Pri zgoraj omenjenih pobudah o zavarovanju Hraških listnekov je zanemarjen pomemben razlog za nastanek opisane kulturne pokrajine v preteklih stoletjih, ki je pomembno prispeval k ohranjeni biološki raznovrstnosti. Gre za razgiban ledeniški relief, ki je nastal kot posledica pleistocenskih poledenitev. V okviru morebitnega zavarovanja Hraških listnekov se torej ne smemo omejiti zgolj na tamkajšnjo favno in floro, temveč moramo vključiti tudi geomorfološko dediščino.

V primeru zavarovanja Hraških listnekov je nujno uskladiti naravovarstvene in kmetijske ukrepe. V primeru omejevanja kmetovanja je treba v okviru programa razvoja podeželja tudi za območje Hraških listnekov v okviru kmetijsko-okoljskih-podnebnih obveznosti (Program razvoja ... 2018) omogočiti

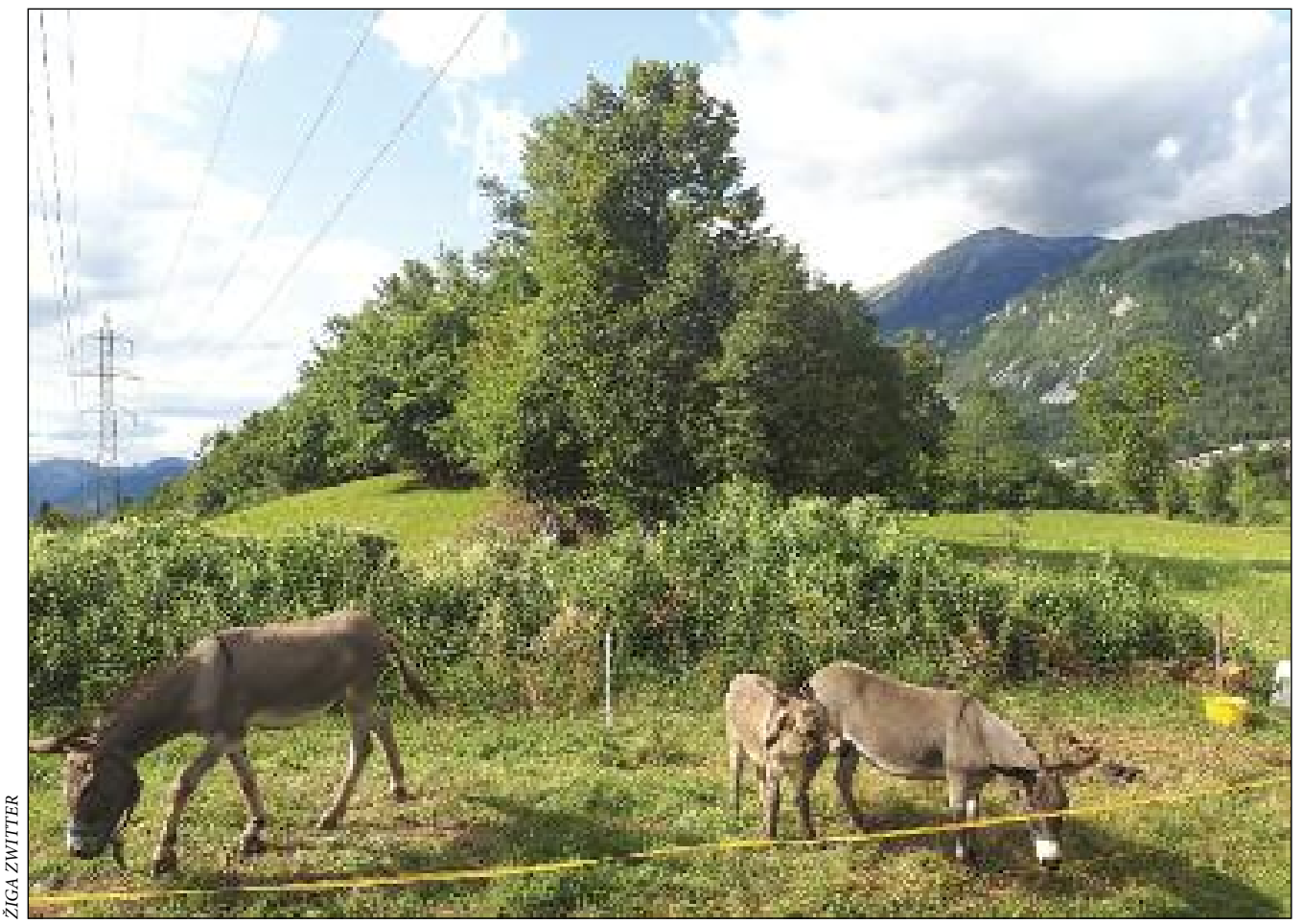

Slika 10: Neznačilen relikt ekstenzivne rabe, ki bo v Hraških listnekih kmalu izginila, ali primer rabe zemljišč, ki bo v prihodnosti bolj razširjena in bo pripomogla k ohranjanju kulturne pokrajine preučevanega območja? 
ustrezno finančno spodbudo kmetom, ki bodo svoje kmetovanje ustrezno prilagodili varovanju naravne in kulturne dediščine. Če bi na primer cena ekološko pridelanega (na primer senenega mleka) dosegala višjo vrednost, bi si kmetje lahko privoščili višje proizvodnje stroške, in bi bili konkurenčni kmetijam $\mathrm{z}$ zemljišči na uravnanem terenu.

Postopke za zavarovanje je treba voditi transparentno ter vanje že v začetnih fazah vključiti tudi lokalno prebivalstvo in ostalo zainteresirano javnost, saj le tako lahko dosežemo ugoden razplet. Kratkoročno bo mnogo več časa treba posvetiti dialogu, predvsem med naravovarstveniki ter kmeti in drugimi lastniki kmetijskih zemljišč. Prostovoljna pomoč naravovarstvenikov pri ustreznih kmetijskih opravilih v Hraških listnekih bi lahko prispevala k izgradnji novega zaupanja in tlakovala pot dolgoročnim ciljem.

Zahvala: Raziskava je bila opravljena v okviru raziskovalnih programov Geografija Slovenije (P6-0101) in Slovenska zgodovina (P6-0235), ki ju financira Javna agencija za raziskovalno dejavnost Republike Slovenije.

\section{Viri in literatura}

Ažman Momirski, L., Kladnik, D. 2009: Preobrazba podeželske kulturne pokrajine v Sloveniji. Georitem 13. Ljubljana.

Blaznik, P. 1975: Bitenj in franciscejski kataster. Loški razgledi 22.

Bračko, F., Sovinc, A., Štumberger, B., Trontelj, P., Vogrin, M. 1994: Rdeči seznam ogroženih ptic gnezdilk Slovenije. Acrocephalus 15-67.

Digitalni ortofotografski posnetek. Geodetska uprava Republike Slovenije. Ljubljana, 2005.

Drobesch, W. 2009: Bodenerfassung und Bodenbewertung als Teil einer Staatsmodernisierung: Theresianische Steuerrektifikation, Josephinischer Kataster und Franziszeischer Kataster. Histoire des Alpes 14.

Emanuelsson, U. 2009: The Rural Landscapes of Europe: How Man Has Shaped European Nature. Värnamo. Evidenca dejanske rabe kmetijskih in gozdnih zemljišč. Ministrstvo za kmetijstvo, gozdarstvo in prehrano. Ljubljana, 2018. Medmrežje: http://rkg.gov.si/GERK/ (20.6. 2018).

Franciscejski kataster za Kranjsko, k. o. Hraše pri Radovljici, L80, Cenilni operat, Catastral Schätzungs Operat der Steuergemeinde Hraschach, Protocoll sämmtlicher Grund- und Bau-Parzellen der Gemeinde Hraschach. Arhiv Republike Slovenije. Ljubljana, ok. 1830.

Franciscejski kataster za Kranjsko, k. o. Hraše pri Radovljici, L80, Cenilni operat, Catastral-SchätzungsElaborat. Arhiv Republike Slovenije. Ljubljana, 1831.

Franciscejski kataster za Kranjsko, k. o. Hraše pri Radovljici, L80, Cenilni operat, Prothocoll (8. 10. 1830). Arhiv Republike Slovenije. Ljubljana, 1830b.

Franciscejski kataster za Kranjsko, k. o. Hraše pri Radovljici, L80, Cenilni operat, Reclamations Verhandlungen über den Catastral Act der Steuergemeinde Hraschach, Gutachten 80/5. Arhiv Republike Slovenije. Ljubljana, 1837.

Franciscejski kataster za Kranjsko, k. o. Hraše pri Radovljici, L80, Cenilni operat, s. n. 80/4. Arhiv Republike Slovenije. Ljubljana, 1830a.

Franciscejski kataster za Kranjsko, k. o. Hraše pri Radovljici, L80, Cenilni operat, Reclamations Verhandlungen über den Catastral Act der Steuergemeinde Hraschach, Erledigung der gemeindeweisen Reclamationen in der Gemeinde Hraschach 80/5. Arhiv Republike Slovenije. Ljubljana, 1839.

Franciscejski kataster za Kranjsko, k. o. Hraše pri Radovljici, L80, list A03. Arhiv Republike Slovenije. Ljubljana, 1826.

Franciscejski kataster za Kranjsko, k. o. Hraše pri Radovljici, L80, Seznam zemljiških parcel. Arhiv Republike Slovenije. Ljubljana, 1827. 
Franciscejski kataster za Kranjsko, k. o. Nova vas, L169, Cenilni operat, Catastral-Schätzungs-Elaborat. Arhiv Republike Slovenije. Ljubljana, 1831a.

Franciscejski kataster za Kranjsko, k. o. Nova vas, L169, Cenilni operat, Einvernehmungs Protocoll (29. 9. 1831). Arhiv Republike Slovenije. Ljubljana, 1831b.

Franciscejski kataster za Kranjsko, k. o. Nova vas, L169, Cenilni operat, Protocoll sämmtlicher Grundund Bau-Parzellen der Gemeinde Neudorf. Arhiv Republike Slovenije. Ljubljana, ok. 1830.

Franciscejski kataster za Kranjsko, k. o. Nova vas, L169, Cenilni operat, Protokoll (18. 8. 1830). Arhiv Republike Slovenije. Ljubljana, 1830b.

Franciscejski kataster za Kranjsko, k. o. Nova vas, L169, Cenilni operat, Reclamations Verhandlungen über den Catastral Act der Steuergemeinde Neudorf, Erledigung der gemeindeweisen Reclamationen in der Gemeinde Neudorf 169/5. Arhiv Republike Slovenije. Ljubljana, 1839.

Franciscejski kataster za Kranjsko, k. o. Nova vas, L169, Cenilni operat, Reclamations Verhandlungen über den Catastral Act der Steuergemeinde Neudorf, Gutachten 169/5. Arhiv Republike Slovenije. Ljubljana, 1837.

Franciscejski kataster za Kranjsko, k. o. Nova vas, L169, Cenilni operat, Reclamations Verhandlungen über den Catastral Act der Steuergemeinde Neudorf, Protocoll 169/1. Arhiv Republike Slovenije. Ljubljana, 1836.

Franciscejski kataster za Kranjsko, k. o. Nova vas, L169, Cenilni operat, s. n. 169/4. Arhiv Republike Slovenije. Ljubljana, 1830a.

Franciscejski kataster za Kranjsko, k. o. Nova vas, L169, Seznam zemljiških parcel. Arhiv Republike Slovenije. Ljubljana, 1827.

Franciscejski kataster za Kranjsko, k. o. Nova vas, L169, list A01, A02. Arhiv Republike Slovenije. Ljubljana, 1826.

Gabrovec, M., Kumer, P. 2019: Land-use changes in Slovenia from the Franciscean Cadaster until today. Acta geographica Slovenica 59-1. DOI: https://doi.org/10.3986/AGS.4892

Geršič, M. 1998: Vpliv košnje in drugih posegov v letu 1997 ob potoku Blatnica na gnezdilne možnosti močvirske trstnice (Acrocephalus palustris). Raziskovalna naloga, Osnovna šola Lesce. Lesce.

Geršič, M. 2017: Hraški steljniki, kulturna pokrajina na robu Dežele. Deželne novice 21-5.

Golec, B. 2010: Zemljiški katastri 18. in 19. stoletja kot vir za stavbno, gradbeno in urbanistično zgodovino slovenskega ozemlja - 2. del. Arhivi 33.

Granda, S. 1994: Zgornja Baška dolina v prvi polovici 19. stoletja. Kronika 42-1.

Ifko, M. 2011: Vejnik. Slovenski etnološki leksikon. Ljubljana.

Ilešič, S. 1950: Sistemi poljske razdelitve na Slovenskem. Dela Inštituta za geografijo SAZU 2. Ljubljana. Kačičnik-Gabrič, A. 2016: Kmečko življenje v Zgornjesavski dolini v 18. in 19. stoletju. Kronika 64-3. Kladnik, D., Kruse, A., Komac, B. 2017: Terraced landscapes: an increasingly prominent cultural landscape type. Acta geographica Slovenica 57-1. DOI: https://doi.org/10.3986/AGS.4770

Kladnik, D., Perko, D., Urbanc, M. 2009: Cultural landscapes in Slovenia from a geographical perspective. Cultural Landscape: Across Disciplines. Krakov.

Klemenčič, M. M. 2006: Teoretski pogledi na razvojne strukture slovenskega podeželja. Dela 25. DOI: https://doi.org/10.4312/dela.25.159-171

Kolar, B. 2012: Življenjski prostor male (poljske) divjadi. Divjad in lovstvo. Ljubljana.

Kozinc, B. 2016: Ustni vir. Hraše.

Krausmann, F. 2008: Land Use and Socio-economic Metabolism in Pre-industrial Agricultural Systems: Four Nineteenth-century Austrian Villages in Comparison. Social Ecology Working Paper 72. Vienna.

Kučan, A. 1998: Krajina kot nacionalni simbol. Ljubljana.

Lidar. Geodetska uprava Republike Slovenije. Ljubljana, 2014-2015.

Lovrenčak, F. 1998: Prsti. Geografski atlas Slovenije. Ljubljana.

Moritsch, A. 1969: Das nahe triester Hinterland: zur wirtschaftlichen und sozialen Entwicklung vom Beginn des 19. Jahrhunderts bis zur Gegenwart. Graz. 
Muhovec, N. 2018: Ustni vir. Hraše.

Mulej, A. 2016: Ustni vir. Lesce.

Ogrin, D. 1996: Podnebni tipi v Sloveniji. Geografski vestnik 68.

Panjek, A. 2015: Kulturna krajina in okolje Krasa. Koper.

Perko, D., Hrvatin, M., Ciglič, R. 2017: Določanje pokrajinskih vročih točk Slovenije. Acta geographica Slovenica 57-1. DOI: https://doi.org/10.3986/AGS.4618

Perko, D., Urbanc, M. 2004: Landscape research in Slovenia. Belgeo 2-3. DOI: https://doi.org/10.4000/belgeo.13618

Petek, F., Urbanc, M. 2004: The Franziscean land cadastre as a key to understanding the 19th century cultural landscape in Slovenia. Acta geographica Slovenica 44-1. DOI: https://doi.org/10.3986/AGS44104

Potočnik Slavič, I. 2010: Endogeni razvojni potenciali slovenskega podeželja. GeograFF 7. Ljubljana.

Pravilnik o uvrstitvi ogroženih rastlinskih in živalskih vrst v rdeči seznam. Uradni list Republike Slovenije 82/2002. Ljubljana.

Program razvoja podeželja, Podukrep M10.1 - Plačilo kmetijskih-okoljskih-podnebnih obveznosti (ukrep KOPOP). Ljubljana, 2018. Medmrežje: https://www.program-podezelja.si/sl/ukrepi-in-podukrepiprp-2014-2020/m10-kmetijsko-okoljska-podnebna-placila/podukrep-10-1-placilo-kmetijsko-okoljskihpodnebnih-obveznosti (30.7.2018).

Rajšp, V., Serše, A. (ur.) 1998: Slovenija na vojaškem zemljevidu 1763-1787, Zv. 4. Ljubljana.

Rezar, S. 2018: Ustni vir. Hraše.

Ribnikar, P. 1982: Zemljiški kataster kot vir za zgodovino. Zgodovinski časopis 36-4.

Rupar, B. 2015: Ustni vir. Lesce.

Seručnik, M. 2014: Countryside on the brink of modernity: Josephinian and Franciscan cadastres as sources for the eco-history of Carniola. Man, Nature and Environment Between the Northern Adriatic and the Eastern Alps in Pre-modern Times. Ljubljana.

Sinobad, J. 1999: Dežela: kulturnozgodovinski oris Radovljiške ravnine. Radovljica.

Smukavec, V. 2017: Ustni vir. Spodnje Podjelje.

Stepančič, D., Kodrič, M., Šrok, D., Šporar, M., Lobnik, F. 1992: Pedološka karta Slovenije 1:25.000. Ljubljana.

Šifrer, M. 1969: Kvartarni razvoj Dobrav na Gorenjskem. Geografski zbornik 11.

Šifrer, M. 1992: Geomorfološki razvoj Blejsko-radovljiške kotline in Dobrav v kvartarju. Radovljiški zbornik. Radovljica.

Šmid Hribar, M. 2016: Varovanje in trajnostni razvoj kulturne pokrajine na primeru Ljubljanskega barja. Georitem 27. Ljubljana.

Trpin, D. 1997: Tolmin z okolico ob koncu 18. in začetku 19. stoletja. Po podatkih iz katastra. Tolminski zbornik 3. Tolmin.

Urbanc, M. 2002: Kulturne pokrajine v Sloveniji. Geografija Slovenije 5. Ljubljana.

Ureditveni načrt za Hraške steljnike. Elaborat, Zavod za gozdove Slovenije, Območna enota Bled. Bled, 2014. Verbič, M. 1969: Škofja Loka v luči cenitve katastrskega dohodka leta 1827 in 1830. Kronika 17-3.

Winiwarter, W. 2016: Method Précis: Working with historical material. Social Ecology: Society-Nature Relations Across Time and Space. Cham.

Zakon o ohranjanju narave. Uradni list Republike Slovenije 56/1999. Ljubljana.

Zapisnik 4. redne seje Sveta Krajevne skupnosti Lesce (11. 6. 2015). Lesce, 2015.

Zemljiški kataster z lastništvom. Geodetska uprava Republike Slovenije. Ljubljana, 2013.

Zupančič, M., Seliškar, A., Žagar, V. 1998: Rastlinstvo. Geografski atlas Slovenije. Ljubljana.

Zwitter, Ž. 2014: Okolje na Kranjskem v 17. stoletju po Slavi vojvodine Kranjske. Studia Valvasoriana. Ljubljana.

Zwitter, Ž. 2019: Historično prilagajanje ekstremnim okoljskim situacijam na Slovenskem s poudarkom na 16. in 17. stoletju: $\mathrm{z}$ nauki za prihodnost. Ljudje in okoljske spremembe skozi čas. GeograFF 21. Ljubljana. 


\section{Summary: Comparing the cultural landscape of Hraški Listneki and farming there in the first half of the nineteenth century and today}

(translated by DEKS d. o. o.)

The conservation and protection of the cultural landscape is an important development challenge for Slovenian rural areas. The Radovljica Plain (also known as Dežela), a flat landscape on the left bank of the Sava River between Žirovnica and Begunje, where the terrain underwent intense glacial and fluvial transformation, is characterized by a patchwork cultural landscape. Due to their rarity and their ecological and other functions, certain cultural landscape types are endangered. One such area that nature conservationists have identified as worthy of protection is Hraški Listneki, a small sparsely wooded area between Hraše, Hlebce, and Studenčice in the Municipality of Radovljica. The municipality commissioned a regulation plan for the area-referred to in that document as Hraški steljniki due to the important role of gathering bedding or litter for animals (Sln. stelja), otherwise referred to with the microtoponym Hraški Listneki. This article investigates land use types and farming practices which were shaping the traditional cultural landscape of Hraški Listneki in the early nineteenth century. Comparison with the current situation makes it possible to understand the past and current biodiversity of the area. The question arises whether the current biodiversity of this area is the result of a conserved historical cultural landscape and practices of using natural resources, or the result of changes in natural resource management over the past two centuries.

Agriculture was the main economic activity in the cadastral municipality of Hraše in the first half of the nineteenth century; arable farming and animal husbandry were both important. Data on all landuse types in the study area recorded in the Franciscean Cadaster for the early nineteenth century were analyzed. Only meadows as the land-use category which strongly prevails in the study area today are presented in detail in this study to answer the key question of what remains similar to nineteenth-century use in this relatively traditional landscape and what has changed significantly. The field pattern in the Hraše cadastral municipality was somewhat unique compared to others in the Radovljica Plain. Forests were rather far from the villages. Therefore, farmers most likely mainly used wooded meadows to gather leaf litter as bedding for animals, and they also gathered litter in the neighboring cadastral municipalities. The leaves of oaks, ashes, and beeches that grew on wooded meadows with forest trees were used as bedding and fodder for sheep and goats. The practice of gathering leaf litter below the trees in this area accompanied the routine spring cleaning of the meadows.

Since the early nineteenth century, some elements of this cultural landscape have been preserved and others have changed. On most farms, the traditional gathering of leaf litter and production of leaf fodder was practiced until around 1950. Because most farmers no longer need leaf litter and leaf fodder, these traditional forms of farming are no longer practiced. Extensification is the predominating process that led to changes in the tilled land of the area, with the former tilled fields now being largely overgrown with grassland plants. Part of the former meadows of the lowest quality in the northeast part of this landscape and the former meadows and tilled land in the center of this cultural landscape east of Hraše are being afforested. By way of exception, in part of the countryside immediately southeast of Hraše, the tilled fields and former belts of meadows that separated individual fields have been converted into intensive orchards. In addition to changes in land-use categories, significant changes occurred in the agricultural practices in the study area. Haymaking now primarily depends on the intensity of farming. The land is mowed more often, the first mowing takes place sooner, spring grazing in meadows is not practised anymore and mineral fertilizers are also applied to some meadows. While oak has been frequent in the early 19th and in the 21st century, the abundance of the large leaved and of the small leaved lime probably increased, but the abundance of ash and beech decreased.

While labour-intensive traditional agriculture crucially contributed to the formation of the studied habitats, two main threats to biodiversity in the study area at present are (1) energy-intensive industrialized 
animal husbandry and (2) abandonment of farming. However, more sustainable farming has still been practised in parts of the study area and a variety of rare bird species still nest there.

In places, the intensification of farming has been so aggressive that it has dramatically changed the character of the cultural landscape. Abandoning the practice of gathering leaf litter over the past years and higher production costs on rough terrain are leading to felling trees, mechanical removal of stumps, and leveling the rough terrain because there is intense grassland cultivation in part of the landscape discussed.

Based on the analysis of selected sources and the situation on the ground, it can be concluded that Hraški Listneki is an interesting cultural landscape that farmers from the surrounding villages created through traditional farming, preserving or transforming its biodiverse habitats over the centuries. To conserve this cultural landscape, it is vital to harmonize farmers' interests on the one hand and nature conservation measures on the other, to introduce suitable payments for farmers, and to educate the local farmers. To reach these goals, advice by nature conservationists should be better adapted to the present situation. 